\title{
Biological Activities of Snowdrop (Galanthus spp., Family Amaryllidaceae)
}

\author{
Chee Kei Kong ${ }^{1,2}$, Liang Ee Low ${ }^{3,4}$, Wei Sheng Siew ${ }^{5}$, Wei-Hsum Yap ${ }^{5}$, Kooi-Yeong Khaw ${ }^{1}$, \\ Long Chiau Ming ${ }^{6}$, Andrei Mocan ${ }^{7,8}$, Bey-Hing Goh ${ }^{1,9,10}$ and Poh Hui Goh ${ }^{6 *}$ \\ ${ }^{1}$ Biofunctional Molecule Exploratory (BMEX) Research Group, School of Pharmacy, Monash University Malaysia, Subang Jaya, \\ Malaysia, ${ }^{2}$ Department of Primary Care Medicine, Faculty of Medicine, University of Malaya, Kuala Lumpur, Malaysia, ${ }^{3}$ Institute of \\ Pharmaceutics, College of Pharmaceutical Sciences, Zhejiang University, Hangzhou, China, ${ }^{4}$ Key Laboratory of Biomedical \\ Engineering of the Ministry of Education, College of Biomedical Engineering and Instrument Science, Zhejiang University, \\ Hangzhou, China, ${ }^{5}$ School of Biosciences, Taylor's University, Subang Jaya, Malaysia, ${ }^{6}$ PAPRSB Institute of Health Sciences, \\ Universiti Brunei Darussalam, Gadong, Brunei, ${ }^{7}$ Department of Pharmaceutical Botany, luliu Ha $\square$ ieganu University of Medicine \\ and Pharmacy, Cluj-Napoca, Romania, ${ }^{8}$ Laboratory of Chromatography, Institute of Advanced Horticulture Research of \\ Transylvania, University of Agricultural Science and Veterinary Medicine, Cluj-Napoca, Romania, ${ }^{9}$ College of Pharmaceutical \\ Sciences, Zhejiang University, Hangzhou, China, ${ }^{10}$ Health and Well-Being Cluster, Global Asia in the 21st Century (GA21) \\ Platform, Monash University Malaysia, Subang Jaya, Malaysia
}

OPEN ACCESS

Edited by:

Lyndy Joy McGaw, University of Pretoria, South Africa

Reviewed by: Pinarosa Avato, University of Bari Aldo Moro, Italy Tosin Abiola Olasehinde, University of Fort Hare, South Africa Nehir Unver Somer,

Ege University, Turkey

*Correspondence: Poh Hui Goh pohhui.goh@ubd.edu.bn

Specialty section: This article was submitted to Ethnopharmacology, a section of the journal Frontiers in Pharmacology

Received: 16 April 2020 Accepted: 17 December 2020 Published: 19 February 2021

Citation: Kong CK, Low LE, Siew WS, Yap W-H, Khaw K-Y, Ming LC, Mocan A, Goh B-H and Goh PH (2021) Biological Activities of Snowdrop (Galanthus

spp., Family Amaryllidaceae).

Front. Pharmacol. 11:552453.

doi: 10.3389/fphar.2020.552453
Snowdrop is an iconic early spring flowering plant of the genus Galanthus (Amaryllidaceae). Galanthus species (Galanthus spp.) are economically important plants as ornaments. Galanthus spp has gained significance scientific and commercial interest due to the discovery of Galanthamine as symptomatic treatment drug for Alzhiermer disease. This review aims to discuss the bioactivities of Galanthus spp including anticholinesterase, antimicrobial, antioxidant and anticancer potential of the extracts and chemical constituents of Galanthus spp. This review highlights that Galanthus spp. as the exciting sources for drug discovery and nutraceutical development.

Keywords: snowdrop, galanthus, bioactivities, galanthamine, lycorine

\section{INTRODUCTION}

Amaryllidaceae family comprises about 85 genera and classified into 1,100 perennial bulb species (Bulduk and Karafakıoğlu, 2019). The genus Galanthus, commonly known as "snowdrop" belongs to the family of Amaryllidaceae. It is a small genus comprises about 20 species of bulbous perennial herbaceous plants, and a small number of subspecies, varieties and natural hybrids (Rønsted et al., 2013; World Checklist of Selected Plant Families, 2020). Galanthus in Greek means "gala" for milk and "anthos" for flower, literally milk-white flowers (Lee, 1999). Native to Europe, their distribution also spread to Asia Minor (southwest Asia) and the Near East, including the eastern parts of Turkey, the Caucasus Mountain and Iran (Figure 1) (Semerdjieva et al., 2019).

Snowdrop are economically important thanks to their ornamental potential and their use as landscape plants (Semerdjieva et al., 2019). Despite their ornamental properties, snowdrops have been used in folk medicine to treat pain, migraine and headache. It contains a variety of secondary metabolites such as flavonoids, phenolics, terpenoids and some important alkaloids that have shown to possess a broad spectrum of biological activities (Semerdjieva et al., 2019). Over the past three decades, many alkaloids isolated from the Galanthus spp. including isoquinoline-like compounds such as caranine, narciclasine, tazettine, narwedine and montanine were reported to exhibit acetylcholinesterase inhibitory potential, antibacterial, antifungal, antiparasitic (malaria), antiviral, antioxidant, anticancer, anti-inflammatory 


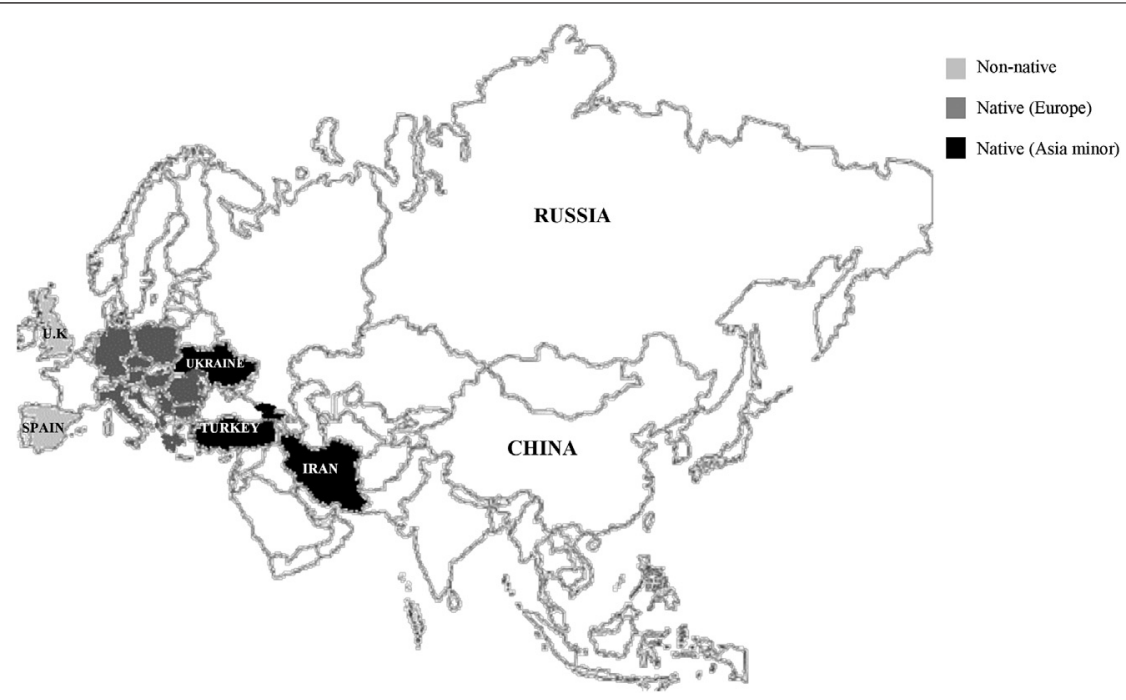

FIGURE 1 | Worldwide's distribution of the Galanthus spp. throughout the United Kingdom and Spain (non-native), Europe (Romania, Bulgaria, etc..) and Southwest Asia (Turkey, Ukraine, Iran).

activities. (Elgorashi et al., 2003; Orhan and Șener, 2003; Ločárek etal., 2015; Resetár et al., 2017). The main constituents with pharmacological action present in the snowdrop, especially in the bulbs are galanthamine and lycorine (Ayaz et al., 2019).
Galanthamine, an alkaloid of Galanthus woronowii Losinsk was reported by Proskurnina and Areshknina in 1947, (Proskurnina and Areshknina, 1953). Also, from the same family, galanthamine was purified and characterized from the bulbs of the G. nivalis L. by

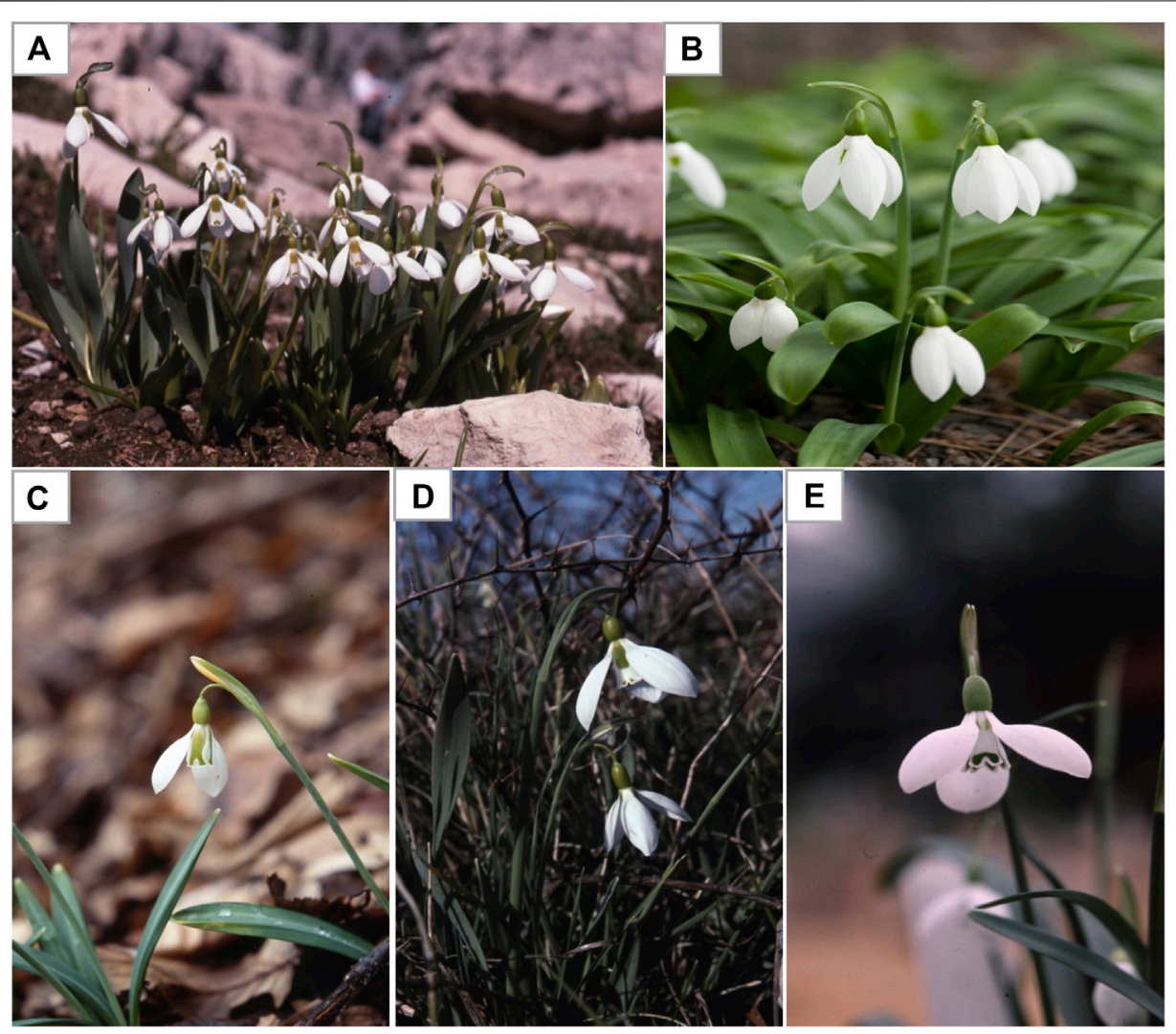

FIGURE 2 | Examples of some commonly found Galanthus spp. (A) Galanthus nivalis (B) Galanthus elwesii (Giant or great snowdrops) (B) Galanthus gracilis (C) Galanthus ikariae (D) Galanthus trojanus. Adapted from Davis (2011). 
TABLE 1 | Galanthus spp.'s common names and scientific names.

Plant common name

Common snowdrop

Giant or great snowdrop

Graceful or slender snowdrop

Ikaria snowdrop

Trojanus snowdrop

Queen Olga's snowdrop

Subspecies of Queen Olga's snowdrop

Hybrids of G. nivalis and G. plicatus subsp. byzantinus

Short snowdrop

Snowdrop Cilician

Gol-e-Barfi

Pleated snowdrop

Subspecies of Pleated snowdrop

Lagodekhsky snowdrop

Green snowdrop or Woronow's snowdrop

Krasnov snowdrop

$\rightarrow$

Broad-leaved snowdrop

Caucasian snowdrop

Kemularia

Rare snowdrop

-

a Not found in http://powo science kew org
Plant full scientific name Kew MPNS

Galanthus nivalis L.

Galanthus elwesii Hook.f.

Galanthus gracilis Celak.

Galanthus ikariae Baker.

Galanthus trojanus A.P.Davis \& Özhatay

Galanthus reginae-olgae Orph.

Galanthus reginae-olgae Orph. subsp. vernalis Kamari

Galanthus xvalentinei nothosubsp. subplicatus ${ }^{a}$

Galanthus rizehensis Stern

Galanthus cilicicus Baker.

Galanthus transcaucasicus Fomin

Galanthus plicatus M.Bieb.

Galanthus plicatus subsp. byzantinus (Baker) D.A.Webb

Galanthus lagodechianus Kem-Nath.

Galanthus woronowii Losinsk.

Galanthus krasnovii Khokhr.

Galanthus alpinus Sosn.

Galanthus platyphyllus Traub \& Moldenke (previously known as G.latifolius)

Galanthus caucasicus (Baker) Grossh. (now accepted as

Galanthus alpinus var. alpinus)

Galanthus kemulariae Kuth. (now accepted as Galanthus lagodechianus

Kem-Nath.)

Galanthus shaoricus Kem-Natha

Galanthus peshmenii A.P.Davis \& C.D.Brickell
Voucher specimen deposition

Royal Botanic Gardens, Kew Royal Botanic Gardens, Kew Royal Botanic Gardens, Kew Royal Botanic Gardens, Kew Royal Botanic Gardens, Kew Royal Botanic Gardens, Kew

-

-

Royal Botanic Gardens, Kew Royal Botanic Gardens, Kew

Royal Botanic Gardens, Kew Royal Botanic Gardens, Kew -

Royal Botanic Gardens, Kew Royal Botanic Gardens, Kew

-

Royal Botanic Gardens, Kew

$-$

$-$

$-$
Dimatar PaskovGalanthamine has been used as the promising drug (known as Nivalin) for the symptometric treatment Alzheimer's disease (AD) (Paskov, 1959; Ayaz et al., 2019). In addition, lectins agglutinin (GNA) were discovered from Galanthus nivalis.

In this review, we discuss the traditional uses and report all published data in relation to their secondary metabolites and biological activities of snowdrops.

\section{THE SNOWDROP PLANTS (GALANTHUS SPP.)}

Snowdrops are tiny plants ( 3 to 6 inches tall) with ( 1 inch or less) white flowers. Each snowdrop bulb produces two linear narrow grassy leaves and a single flower with a delicate small white drooping bell shaped flower. The snowdrop has no petal, but tepal. The outer three are longer pure white, while the smaller inner three are shorter and blushed with green markings (Aschan and Pfanz, 2006). There are many different varieties and species of snowdrop flowers that differs in terms of the size of the tepals and the green markings. As the name suggests, snowdrops are winter-to-spring flowering plants, of which Galanthus nivalis is the first and most common species of the genus (Figure 2; Table 1) to bloom during the end of the winter taking advantage of the lack of tree canopy to capture sunlight for photosynthesis and growth (Orhan and Şener, 2003). Wild snowdrops grow in damp soil in the temperate deciduous woodlands, for example oak (Quercus spp.), maple (Acer spp.), pines (Pinus spp.), cedar of Lebanon (Cedrus libani), particularly nearby shady areas, near river or streams (Elgorashi et al., 2003). Galanthus spp. are difficult to distinguish and classify due to high variability of morphological characteristics which is not clearly definable, which led to multiple taxonomic revisions Galanthus over the years (Rønsted et al., 2013). Currently, all species of Galanthus are classified as Critically Endangered (CR) under International Union for Conservation of Nature (IUCN) Red List Categories and Appendix II of the Convention on International Trade (CITES) in the list of Wild Fauna and Flora. The endangered status of Galanthus is due to its susceptibility to climate change, plucking and forestry and unregulated Galanthus bulb trade (International Union for Conservation of Nature, 2018). It is noteworthy that under CITES regulations, only rural communities in many countries are allowed in limited wild harvest and trade of just three species (G. nivalis, $G$. elwesii, and G. woronowii) (Bishop et al., 2001).

\section{SNOWDROP IN FOLKLORE}

For centuries, the snowdrops have been used as a remedial herb to ease migraines and headaches. Plaitakis and Duvoisin believed the oldest record on snowdrop (Galanthus nivalis L.) was found in ancient Homer's epic poem, where snowdrop is described as 'moly' and used by Odysseus as an antidote against Circe's poisonous drugs (Plaitakis and Duvoisin, 1983). According to an unconfirmed report in the early 1950s, a Bulgarian pharmacologist noticed people of the remote areas rubbing their foreheads with the plant leaves and bulbs as a folk remedy to relieve nerve pain (Mashkovsky and Kruglikova-Lvova, 1951). Besides, some of the earlier publications had left traces that of evidences on the extensive use of snowdrop in Eastern Europe, such as Romania, Ukraine, the Balkan Peninsula, as well as in some Eastern 


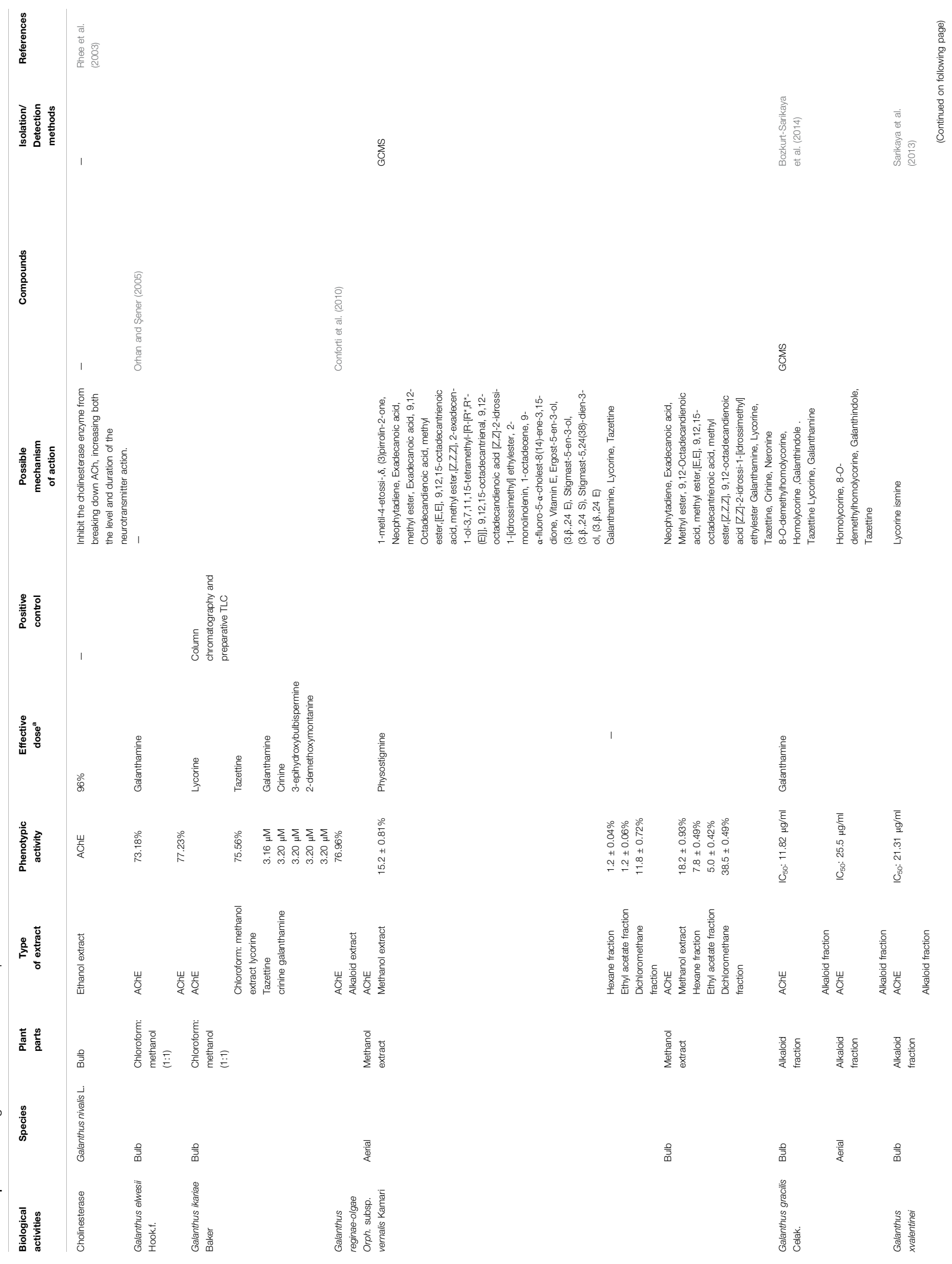




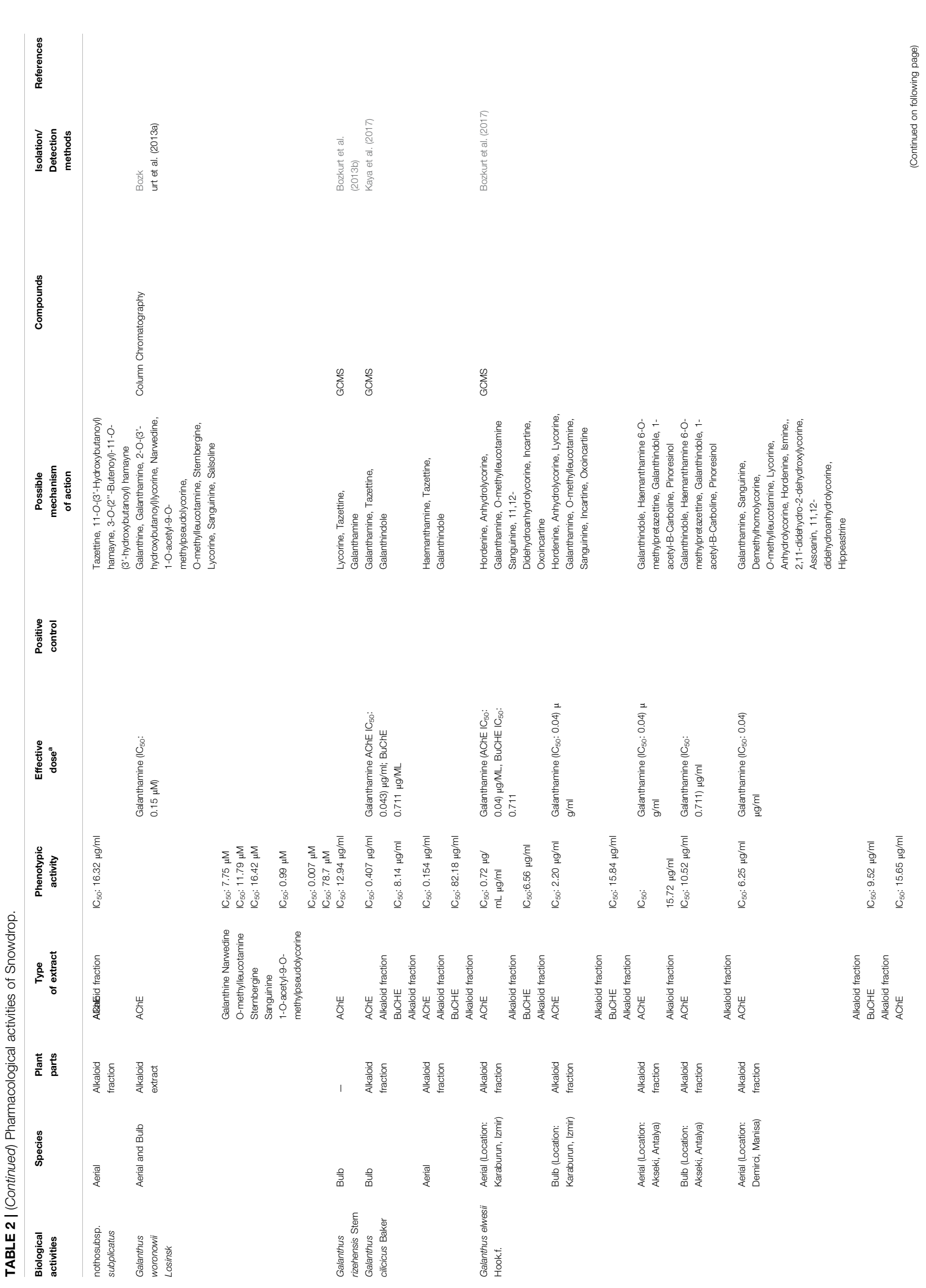


I

II

Min

III

$\sum_{0}^{\infty}$

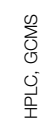

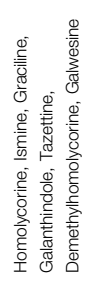

$\sum_{\substack{\infty \\ 0}}^{\infty}$

$\sum_{0}^{\infty}$

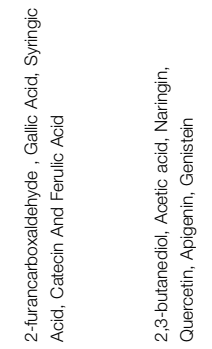

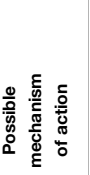
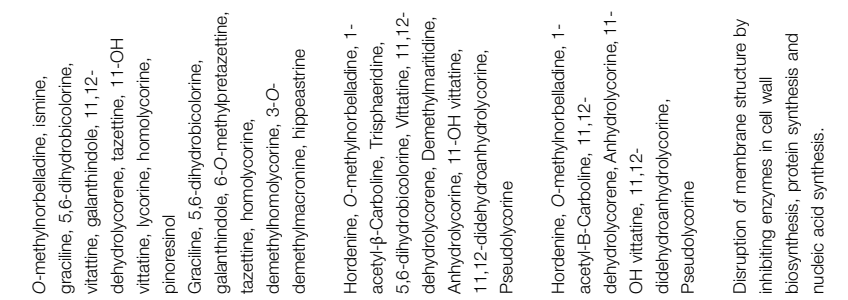

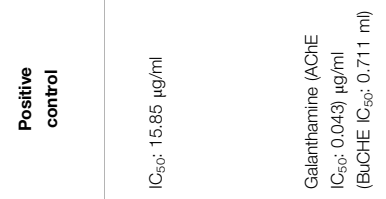

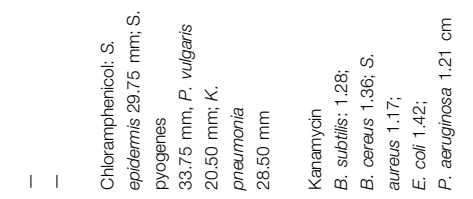

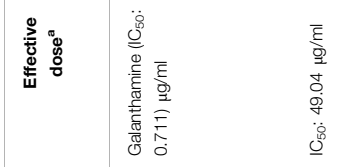

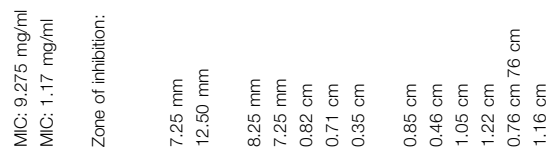

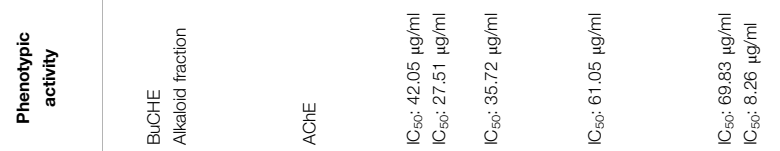

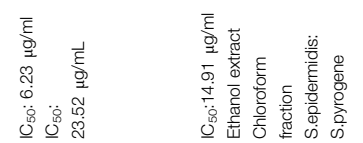

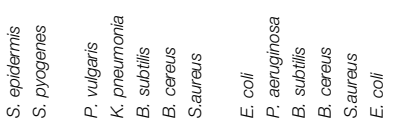

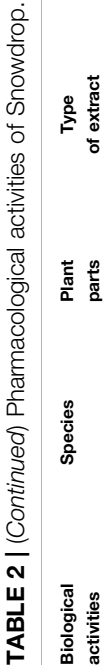

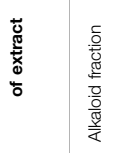

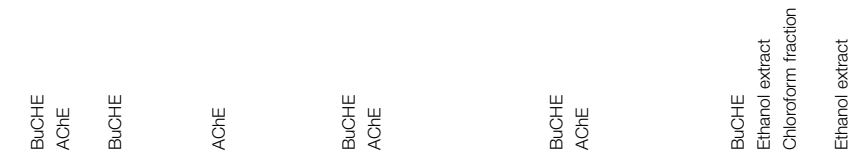

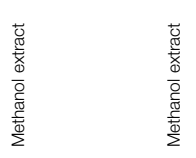

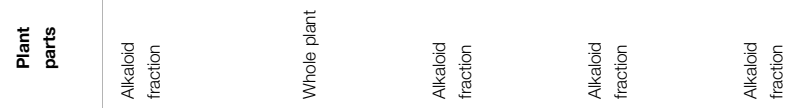

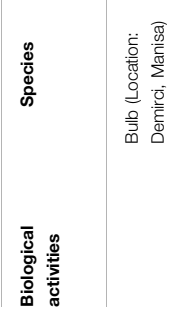

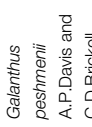

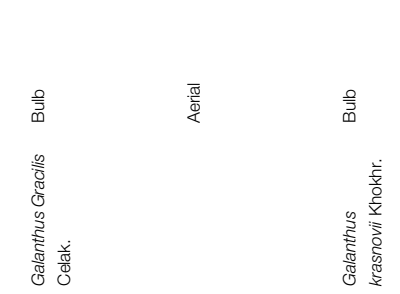

高 产

高旁言 

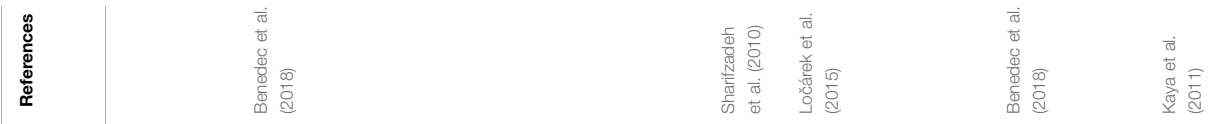

In

옴

$\sum_{\substack{\infty \\ 0}}^{\infty}$

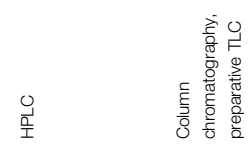
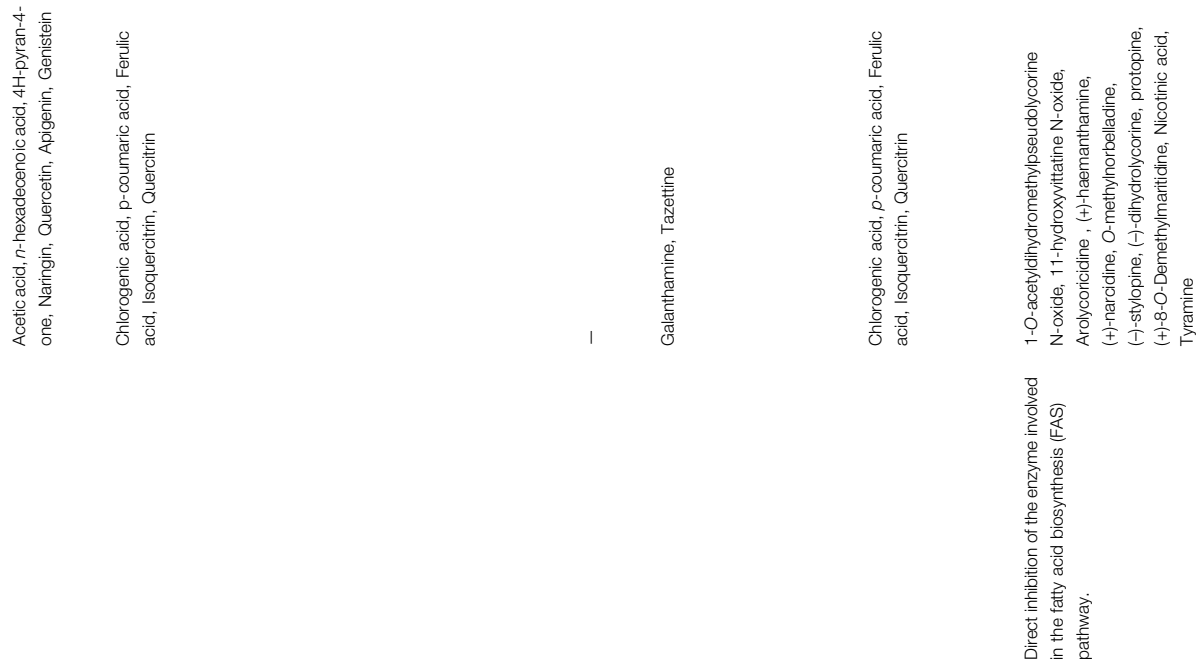

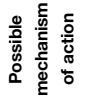

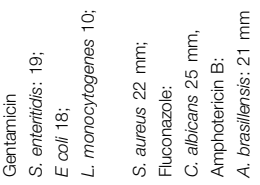

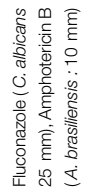
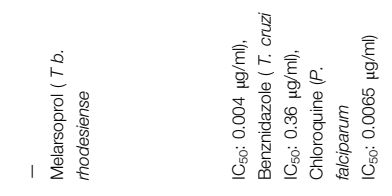

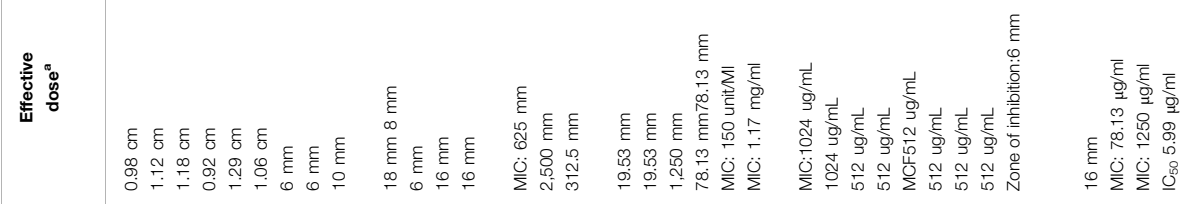
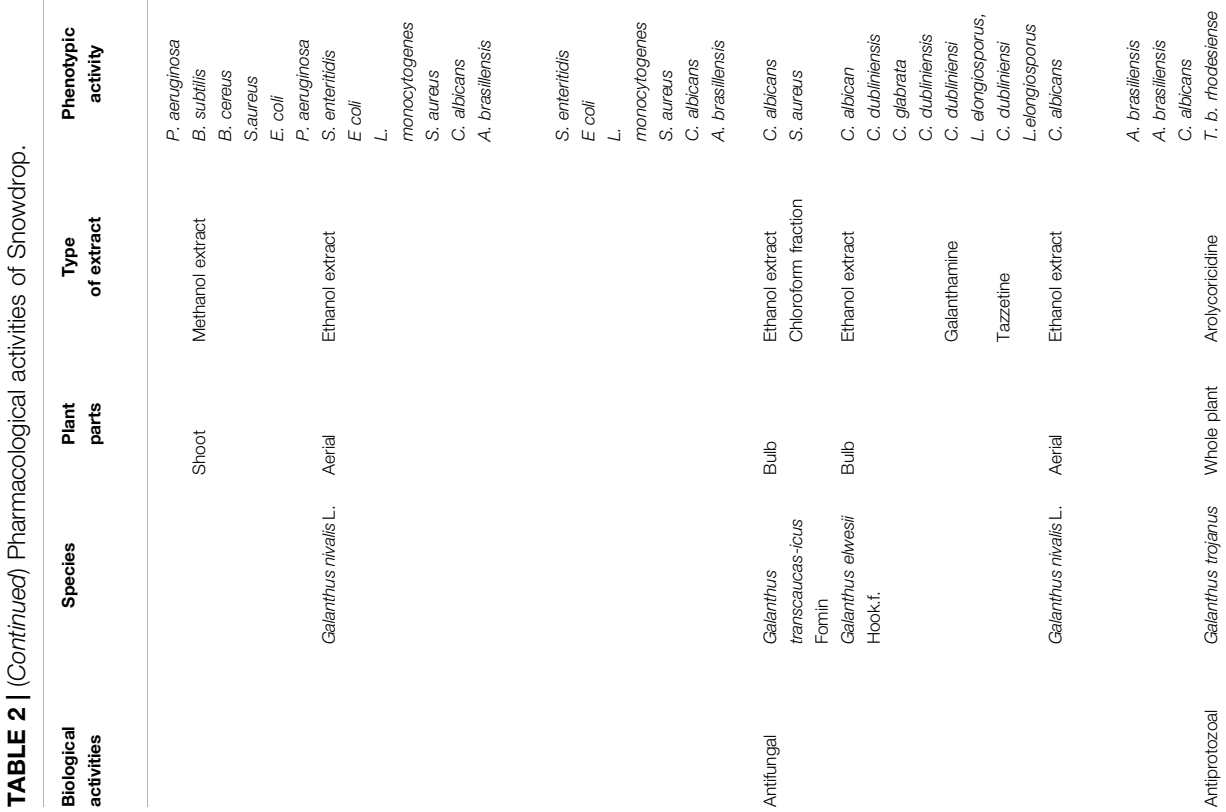

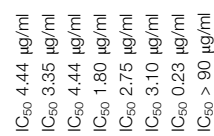
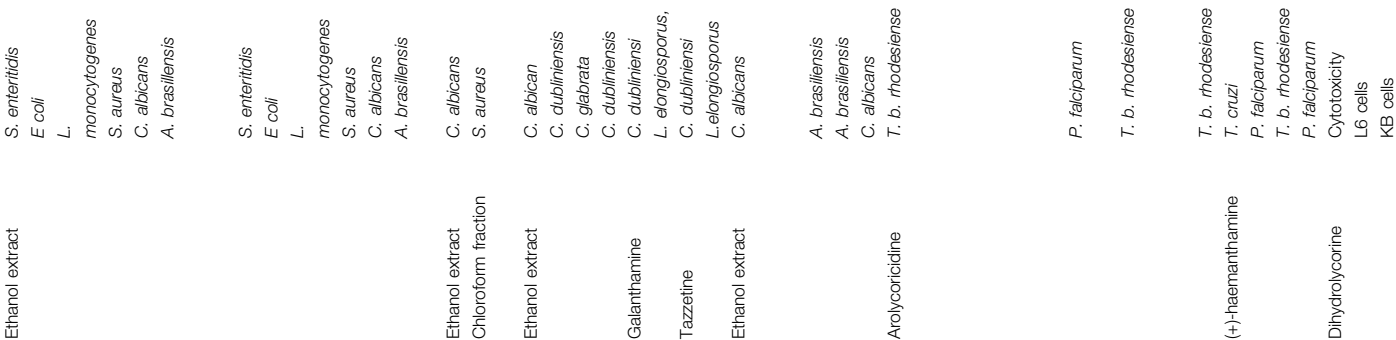

产

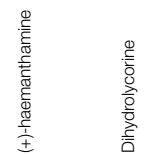




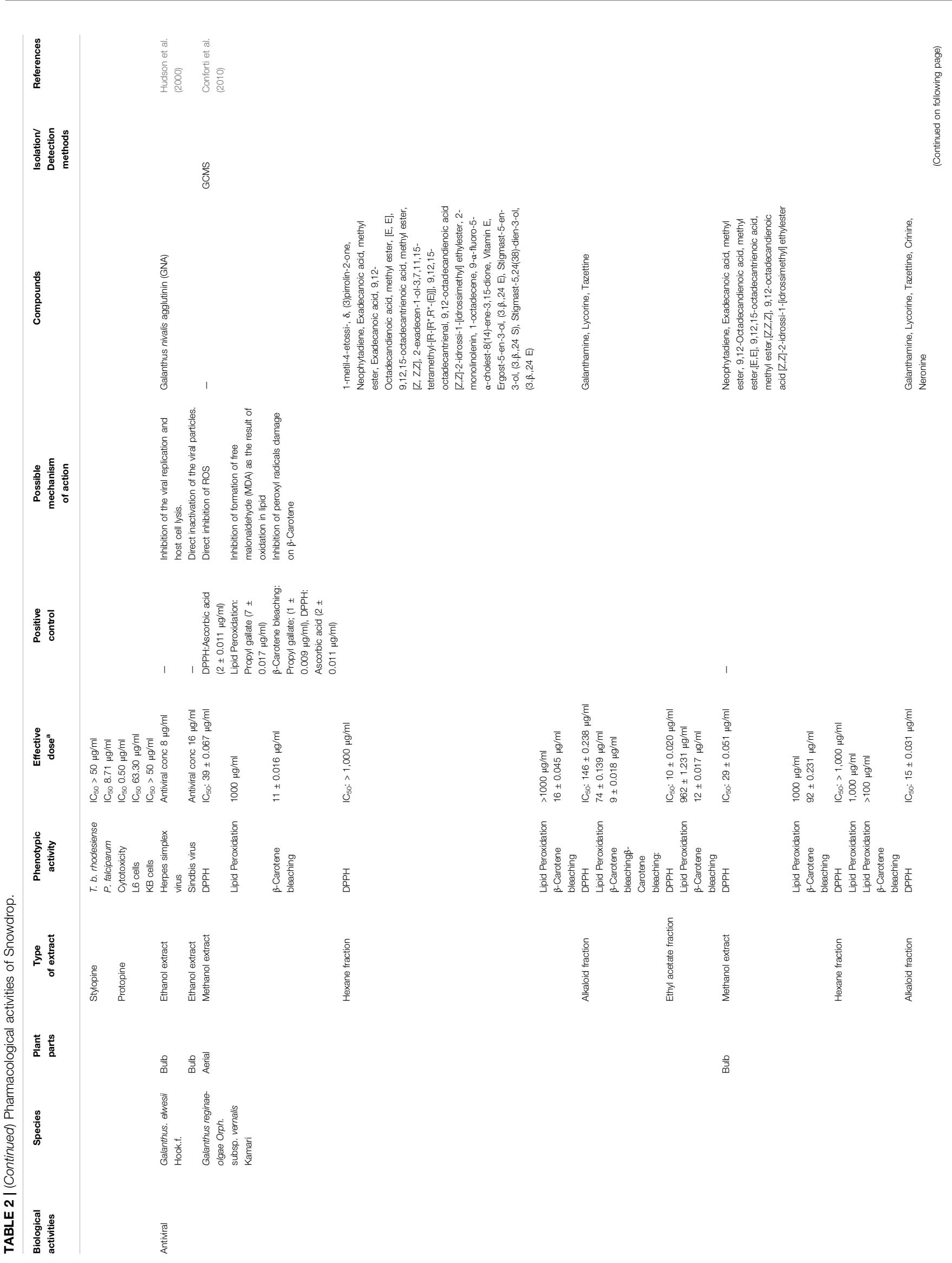




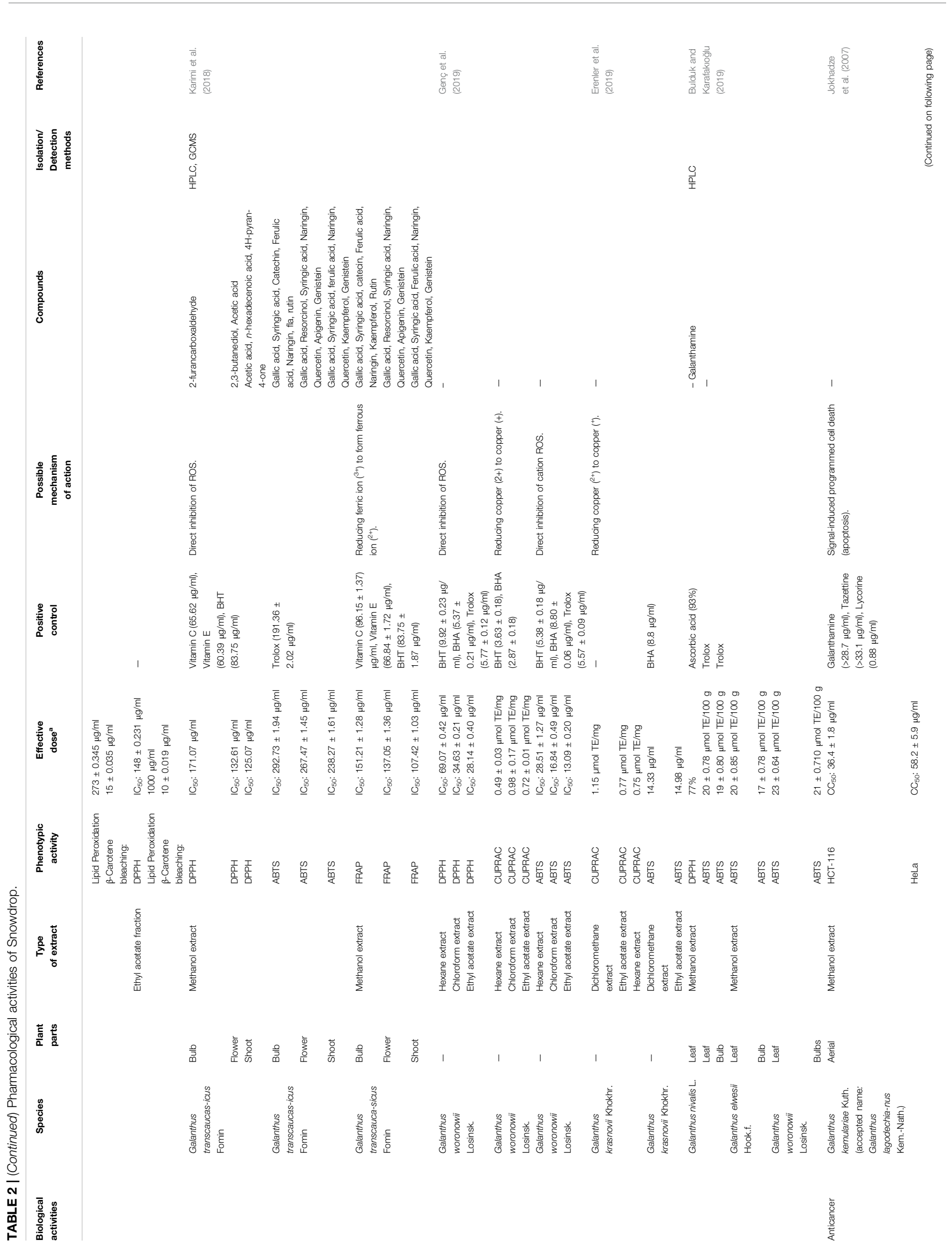


TABLE 2 | (Continued) Pharmacological activities of Snowdrop.

\begin{tabular}{|c|c|c|c|c|c|c|c|c|c|c|}
\hline $\begin{array}{l}\text { Biological } \\
\text { activities }\end{array}$ & Species & $\begin{array}{l}\text { Plant } \\
\text { parts }\end{array}$ & $\begin{array}{c}\text { Type } \\
\text { of extract }\end{array}$ & $\begin{array}{l}\text { Phenotypic } \\
\text { activity }\end{array}$ & $\begin{array}{l}\text { Effective } \\
\text { dose }^{a}\end{array}$ & $\begin{array}{l}\text { Positive } \\
\text { control }\end{array}$ & $\begin{array}{l}\text { Possible } \\
\text { mechanism } \\
\text { of action }\end{array}$ & Compounds & $\begin{array}{l}\text { Isolation/ } \\
\text { Detection } \\
\text { methods }\end{array}$ & References \\
\hline & & Bulb & Methanol extract & $\begin{array}{l}\text { HL-60 } \\
\text { HCT-116 } \\
\text { HeLa } \\
\text { HL-60 }\end{array}$ & $\begin{array}{l}C^{C} C_{50}: 53.8 \pm 6.4 \mu \mathrm{gg} / \mathrm{ml} \\
C_{50}: 12.2 \pm 2.7 \mu \mathrm{gg} / \mathrm{ml} \\
C_{50}: 37.1 \pm 4.7 \mathrm{\mu g} / \mathrm{ml} \\
C_{50}: 34.3 \pm 3.9 \mathrm{\mu g} / \mathrm{ml}\end{array}$ & & & & & \\
\hline & $\begin{array}{l}\text { Galanthus } \\
\text { lagodechia-nus } \\
\text { Kem.-Nath. }\end{array}$ & Bulb & Methanol extract & HCT-116 & $\mathrm{CC}_{50}: 11.1 \pm 3.4 \mu \mathrm{\mu g} / \mathrm{ml}$ & $\begin{array}{l}\text { Galanthamine } \\
(>28.7 \mu \mathrm{g} / \mathrm{m}) \text {, Tazettine } \\
(>33.1 \mu \mathrm{g} / \mathrm{m}) \text {, Lycorine }\end{array}$ & & - & & \\
\hline & & & & $\begin{array}{l}\text { HeLa } \\
\text { HL-60 }\end{array}$ & $\begin{array}{l}\mathrm{CC}_{50}: 34.8 \pm 6.3 \mathrm{\mu g} / \mathrm{ml} \\
C \mathrm{CS}_{50}: 45.6 \pm 3.5 \mathrm{\mu g} / \mathrm{ml}\end{array}$ & $(0.88 \mu \mathrm{gg} / \mathrm{ml})$ & & & & \\
\hline & $\begin{array}{l}\text { Galanthus } \\
\text { woronowii } \\
\text { Losinsk. }\end{array}$ & Aerial & Methanol extract & HCT-116 & $\begin{array}{l}\mathrm{C}_{50}: 45: 6 \pm 3.5 \mu \mathrm{\mu g} / \mathrm{ml} \\
\mathrm{CC}_{50}: 22.0 \pm 3.8 \mu \mathrm{ml}\end{array}$ & $\begin{array}{l}\text { Galanthamine } \\
(>28.7 \mu \mathrm{g} / \mathrm{mll)} \text {, Tazettine } \\
(>33.1 \mu \mathrm{g} / \mathrm{ml}) \text {, Lycorine }\end{array}$ & & - & & \\
\hline & & & & $\begin{array}{l}\text { HeLa } \\
\text { HL-60 }\end{array}$ & $\begin{array}{l}\mathrm{CC}_{50}: 41.3 \pm 3.3 \mathrm{\mu g} / \mathrm{ml} \\
\mathrm{CC}^{\circ 5}: 39.4 \pm 2.8 \mathrm{\mu g} / \mathrm{ml}\end{array}$ & $(0.88 \mu \mathrm{g} / \mathrm{m})$ & & & & \\
\hline & $\begin{array}{l}\text { Galanthus } \\
\text { krasnovii Khokhr. }\end{array}$ & Bulb & Methanol extract & HCT-116 & $\mathrm{CC}_{50}: 5.8 \pm 0.9 \mu \mathrm{g} / \mathrm{ml}$ & $\begin{array}{l}\text { Galanthamine } \\
(>28.7 \mu \mathrm{g} / \mathrm{m}) \text {, Tazettine }\end{array}$ & & - & & \\
\hline & & & & HeLa & $\mathrm{CC}_{50}: 15.4 \pm 3.7 \mu \mathrm{gg} / \mathrm{ml}$ & (>33.1 $\mu \mathrm{g} / \mathrm{ml})$, Lycorine & & & & \\
\hline & & & & HL-60 & $\mathrm{CC}_{50}: 13.8 \pm 1.2 \mathrm{\mu g} / \mathrm{ml}$ & $(0.88 \mu \mathrm{g} / \mathrm{ml})$ & & & & \\
\hline & & Bulb & Methanol extract & $\begin{array}{l}\text { HCT-116 } \\
\text { HeLa }\end{array}$ & $\begin{array}{l}C_{50}{ }_{50}: 7.7 \pm 1.6 \mu \mathrm{g} / \mathrm{ml} \\
C_{50}: 18.9 \pm 3.9 \mu \mathrm{gg} / \mathrm{ml}\end{array}$ & & & & & \\
\hline & & & & HL-60 & $\mathrm{CC}_{50}: 22.0 \pm 2.4 \mu \mathrm{g} / \mathrm{ml}$ & & & & & \\
\hline & $\begin{array}{l}\text { Galanthus alpinus } \\
\text { Sosn. }\end{array}$ & Bulb & Methanol extract & HCT-116 & $\mathrm{CC}_{50}: 9.6 \pm 0.8 \mu \mathrm{g} / \mathrm{ml}$ & $\begin{array}{l}\text { Galanthamine } \\
(>28.7 \mu \mathrm{g} / \mathrm{m}) \text {, Tazettine }\end{array}$ & & - & & \\
\hline & & & & HeLa & $\mathrm{CC}_{50}: 21.3 \pm 4.5 \mathrm{\mu g} / \mathrm{ml}$ & (>33.1 $\mu \mathrm{g} / \mathrm{ml})$, Lycorine & & & & \\
\hline & & & & $\mathrm{HL}-60$ & $\mathrm{CC}_{50}: 23.7 \pm 1.7 \mu \mathrm{g} / \mathrm{ml}$ & $(0.88 \mu \mathrm{g} / \mathrm{ml})$ & & & & \\
\hline & $\begin{array}{l}\text { Galanthus } \\
\text { shaoricus Kem.- } \\
\text { Nath. }\end{array}$ & Bulb & Methanol extract & HCT-116 & $\mathrm{CC}_{50}: 8.9 \pm 1.6 \mu \mathrm{g} / \mathrm{ml}$ & $\begin{array}{l}\text { Galanthamine } \\
(>28.7 \mu \mathrm{g} / \mathrm{m}) \text {, Tazettine } \\
(>33.1 \mu \mathrm{g} / \mathrm{m}) \text {, Lycorine }\end{array}$ & & - & & \\
\hline & & & & $\begin{array}{l}\text { HeLa } \\
\text { HL-60 }\end{array}$ & $\mathrm{CC}_{50}: 17.2 \pm 2.1 \mathrm{\mu g} / \mathrm{ml}$ & $(0.88 \mu \mathrm{g} / \mathrm{ml})$ & & & & \\
\hline & $\begin{array}{l}\text { Galanthus } \\
\text { platyphyllu-s Traub } \\
\text { and Moldenke }\end{array}$ & Bulb & Methanol extract & $\begin{array}{l}\text { HL-60 } \\
\text { HCT-116 }\end{array}$ & $\begin{array}{l}\mathrm{C}_{50}: 16: 4 \pm 0.9 \mu \mathrm{\mu g} / \mathrm{ml} \\
\mathrm{CC}_{50}: 14.2 \pm 2.7 \mu \mathrm{ml}\end{array}$ & $\begin{array}{l}\text { alanthamine }(>28.7 \mu \mathrm{g} / \\
\mathrm{ml}) \text {, Tazettine }(>33.1 \mu \mathrm{\mu g} / \\
\mathrm{ml}) \text {, Lycorine }\end{array}$ & & - & & \\
\hline & & & & $\begin{array}{l}\text { HeLa } \\
\text { HL-60 }\end{array}$ & $\begin{array}{l}C_{50}: 11.5 \pm 1.7 \mu \mathrm{g} / \mathrm{ml} \\
C^{C C_{50}: 19.1 \pm 1.0 \mu \mathrm{g} / \mathrm{ml}}\end{array}$ & $(0.88 \mu \mathrm{g} / \mathrm{ml})$ & & & & \\
\hline & Galanthus & Aerial & Methanol extract & HCT-116 & $\mathrm{CC}_{50}: 49.5 \pm 4.8 \mathrm{\mu g} / \mathrm{ml}$ & Galanthamine & & - & & \\
\hline & $\begin{array}{l}\text { caucasicus (Baker) } \\
\text { Grossh. (accepted } \\
\text { name: Galanthus }\end{array}$ & & & $\begin{array}{l}\text { HeLa } \\
\text { HL-60 }\end{array}$ & $\begin{array}{l}\mathrm{CC}_{50}: 42.8 \pm 2.8 \mu \mathrm{\mu g} / \mathrm{ml} \\
\mathrm{C}_{50}: 39.3 \pm 2.3 \mathrm{\mu g} / \mathrm{ml}\end{array}$ & $\begin{array}{l}(>28.7 \mu \mathrm{g} / \mathrm{m}) \text { ), Tazettine } \\
(>33.1 \mu \mathrm{m} / \mathrm{m}) \text {, Lycorine } \\
(0.88 \mu \mathrm{g} / \mathrm{m})\end{array}$ & & & & \\
\hline & $\begin{array}{l}\text { alpinus var. } \\
\text { alpinus) }\end{array}$ & Bulb & Methanol extract & HCT-116 & $\mathrm{CC}_{50}: 23.4 \pm 3.7 \mu \mathrm{g} / \mathrm{ml}$ & $\begin{array}{l}\text { Galanthamine } \\
(>28.7 \mu \mathrm{g} / \mathrm{mll}), \text { Tazettine } \\
(>33.1 \mu \mathrm{g} / \mathrm{ml}) \text {, Lycorine } \\
(0.88 \mu \mathrm{g} / \mathrm{ml})\end{array}$ & & & & \\
\hline & & & & $\begin{array}{l}\text { HeLa } \\
\text { HL-60 }\end{array}$ & $\begin{array}{l}\mathrm{CC}_{50}: 32.1 \pm 3.7 \mu \mathrm{g} / \mathrm{ml} \\
{ } C_{50}: 31.9+1.5 \mu / \mathrm{ml}\end{array}$ & & & & & \\
\hline
\end{tabular}

${ }^{a}$ Effective dose: Dose that gives significant results with $p<0.05, p<0.01, p<0.001$.

${ }^{1} \mathrm{H}$-NMR, hydrogen-1 nuclear magnetic resonance; $A B T S, 2,2$ '-azino-bis(3-ethylbenzothiazoline-6-sulfonic acid); $A C h$, acetylcholine; $A C h E$, acetylcholinesterase; $B H A$, butylated hydroxyanisole; $B H T$, butylated hydroxytoluene; $C C_{50}$, half maximal cytotoxic and inhibitory concentration; DPPH, 2,2-diphenyl-1-picry/hydrazyl; EC $_{50}$, half maximal effective concentration; EIMS, electron ionization mass spectrometry; GC-MS, gas chromatography-mass spectrometry; HPLC, high performance liquid chromatography, IC $C_{50}$, half maximal inhibitory concentration; MIC, minimal inhibitory concentration; MFC, minimal fungicidal concentration; NA, no activity; NMR, nuclear magnetic resonance; ROS, reactive oxygen species; SE, standard error; TLC, thin layer chromatography. 


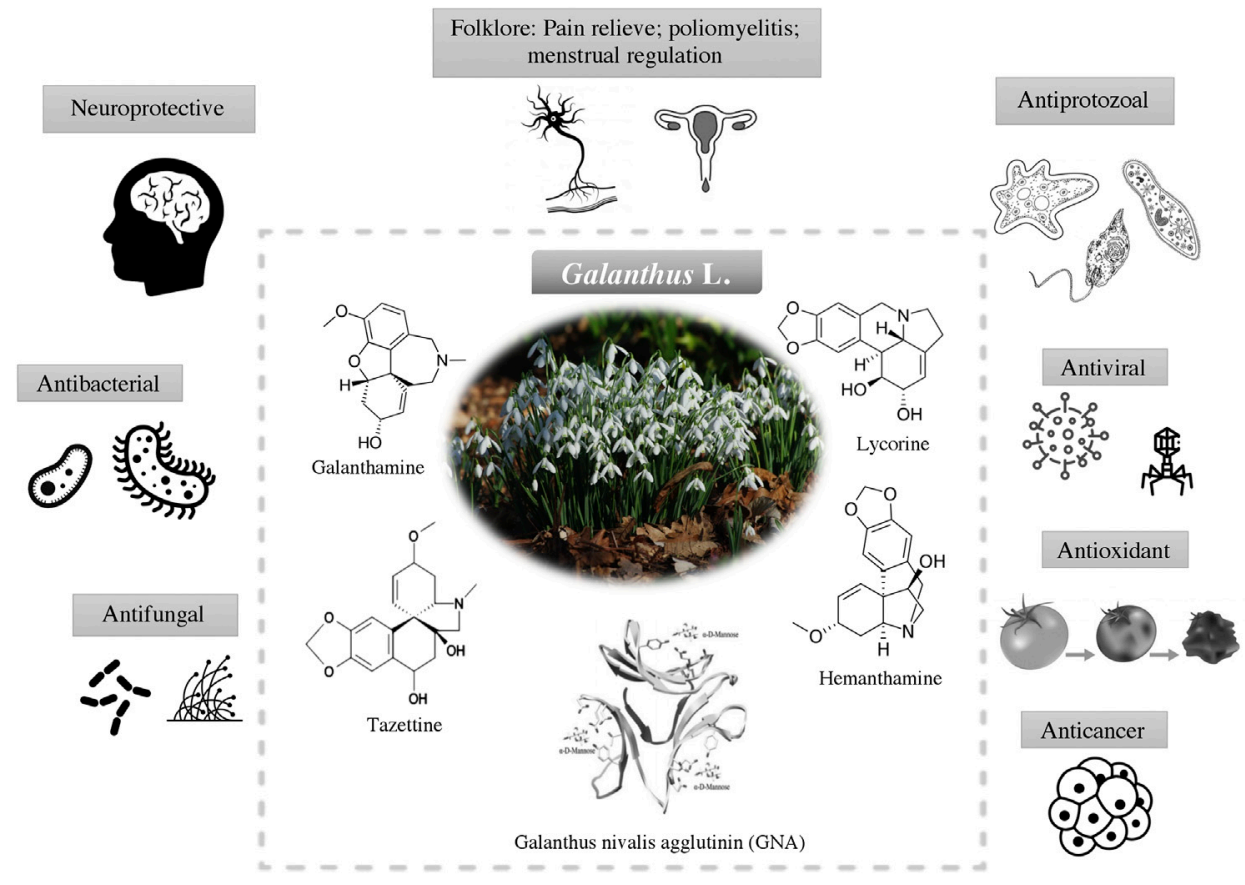

FIGURE 3 | Biological activities of Galanthus spp. and their main bioactive constituents (alkaloids and plant lectin) that contributed to these activities.

Mediterranean countries (Heinrich, 2010). However, there were no relevant ethnobotanical literatures for confirmation to be located. Russian pharmacologists reported that local villagers at the foot of the Caucasian mountains in Georgia used the decoction of the bulbs of wild snowdrop (G. woronowii Los.) for the treatment of poliomyelitis in children (Sidjimova et al., 2003). Besides, an old glossary also classified snowdrop as cardiotonic, stomachic and emmenagogue (Baytop, 1999). The use of Galanthus herb has shown to increase the flow of menstrual blood to cure dysmennorhea or oligomennorhea, and was once used to induce an abortion if in the early stages of pregnancy (Baytop, 1999). Although snowdrops have a long traditional use in folk medicines, the chemical constituent recently become a commercial proposition (Ay et al., 2018). Snowdrops have attracted attention due to its pharmacological potential (wild snowdrops trade) and the chemical diversity (Sidjimova et al., 2003). It is interesting to note that, the bulb of the plant contains a chemical called phenanthridine alkaloid, which is toxic to animals including dogs and cats and may lead to gastrointestinal disorders in humans. Lycorine, the phenanthridine alkaloid is used in herbal medicines and pharmaceutical drugs over the years (Lamoral-Theys et al., 2009).

\section{BIOLOGICAL SUBSTANCES OF SNOWDROP AND THEIR ETHNOPHARMACOLOGY}

Having evolved over millions of years and wide application in traditional medicine. The discovery of new drug from snowdrops begin in the new decade. The discovery of galanthamine has attracted the interest from scientific community to further explore the relationships between the underexplored pharmacological properties of snowdrops and its chemical space. This including the antimicrobial, antioxidant and anticancer activities (Figure 3). The active compounds which are responsible for the biological activities are listed in Table 2.

\section{Anticholinesterase Activity}

Acetylcholinesterase (AChE), aenzyme remain a highly viable target to alleviate the symptoms of Alzheimer's disease (AD) (Kostelník and Pohanka, 2018). AChE (specific cholinsterase) is present in nervous system and terminates neurotransmission, while the activity of BChE is increase during the late stage of AD (Mesulam and Geula, 1994; Khaw et al., 2014; Kostelník and Pohanka, 2018). Galanthamine is known to enhance the activity of acetylcholine (ACh) by inhibiting the enzyme AChE and functions as a nicotinic activator by interacting with nicotinic ACh receptors (nAChRs) in the brain (Maelicke et al., 1997). The interaction between the Ach inhibitor and $\mathrm{nAChR}$ induces conformational change of the receptor molecule, and subsequent activation of nAChRs is believed to have protective effects against $\beta$-amyloid cytotoxicity of neuron cells (Coyle and Kershaw, 2001). Snowdrops are important source of antineurodegeneration compound "galanthamine" thanks to the traditional knowledge in which the extract has been used in folk medicine for neurological conditions (Ago et al., 2011). Due to limited number of drugs available for the management of Alzheimer disease, significant efforts have been made to explore anticholinesterase inhibitor from medicinal plants (Khaw et al., 2014; Tan et al., 2014; Jamila et al., 2015; Liew et al., 2015; Khaw et al., 2020). 
The anti-cholinesterase activities of the Galanthus spp including Galanthus Nivalis, Galanthus elwesii, Galanthus ikariae, Galanthus gracilis, Galanthus xvalentinen, Galanthus rizehensis, Galanthus cilicicus, were assessed in-vitro by determining their inhibitory activities via Ellman method (Table 2). Rhee et al. (2003) showed that the methanol extract of $G$. nivalis had $96 \%$ inhibition against AChE (Rhee et al., 2003). Chloroform:methanol (1:1) extracts of the bulbs of G. elwesii and G. ikariae inhibited AChE at 73.18 and $75.56 \%(10 \mu \mathrm{g} / \mathrm{ml})$, comparable to the alkaloid extracts at 77.23 and $76.96 \%(10 \mu \mathrm{g} / \mathrm{ml})$ (Orhan and Şener, 2005). Phytochemical study of alkaloid extract of $G$. ikariae yielded amaryllidaceae-type alkaloids, including lycorine $\left(\mathrm{IC}_{50}=3.16 \mu \mathrm{M}\right)$, tazettine, crinine, galanthamine $\left(\mathrm{IC}_{50}=3.2 \mu \mathrm{M}\right)$, 3-epi-hydroxybulbispermine and 2 demethoxymontanine. A study of Kaya and colleagues demonstrated that bulb and aeries parts of G. cilicicus selective towards AChE than BuChE, suggesting the present of selective AChE compounds within the extract.

Similarly, methanol extracts of the bulb and aerial part of $G$. elwesii were selectively inhibited AChE (Bozkurt et al., 2013a; Kaya et al., 2017). Subsequent GCMS analysis revealed the present of alkaloids in the G. elwesii extract including Galanthamine, O-methylleucotamine, hordenine and sanguinine (Bozkurt et al., 2017). The alkaloid extracts of the $G$. gracilis bulb and $G$. xvalentinei nothosubsp. Subplicatus were moderately inhibiting AChE with the $\mathrm{IC}_{50}$ of $11.82-25.5 \mu \mathrm{g} / \mathrm{ml}$ (Sarikaya et al., 2013; Bozkurt-Sarikaya et al., 2014). The bulb of G. krasnovii alkaloid was dual cholinesterase inhibitor with the $\mathrm{IC}_{50}$ of $8.26 \mu \mathrm{g} / \mathrm{ml}$ (AChE) and $\mathrm{IC}_{50}$ of $6.23 \mu \mathrm{g} / \mathrm{ml}$ (BuChE) (Bozkurt et al., 2020). GCMS analysis revealed that anhydrolycorine and 11,12didehydroanhydrolycorine were the dominant compounds in the extract contribute to the inhibitory activities.

The findings showed that alkaloids from Galanthus spp played an important role in cholinesterase inhibitory activities. Among the alkaloids, lycorine-type alkaloids dominated in the studied extracts. Galanthamine and tazettine-type alkaloids were present in very low amounts. The alkaloid content in the bulb was more prominent than the aerial parts. The findings showed that inhibitory activity might be due to the synergistic interactions between the alkaloids within the extract. Taking into account that existing drugs are effective mild to moderate progression of $\mathrm{AD}$ and presenting considerable side effects, the search for effective and selective cholinesterase inhibitors with minimum side effects is imperative. It can be conclude that, the bulb of Galanthus spp. can be served as a source of anticholinesterase alkaloids in addition to their ornamental properties.

\section{Antimicrobial Activity}

The emergence of new infectious diseases and drug resistance to antibiotic is one of the biggest threats to global health (Ventola, 2015). Antimicrobial, including antibacterial, antifungal, antiviral and antiprotozoal agents are becoming ineffective, attributed to the overuse and misuse of current existing drugs which leads to resistance (Interagency Coordination Group, 2019). On top of that, diminishing antibiotic pipeline resulted in lesser treatment options against multiple drug resistance pathogens and responsible for at least 700,000 casualties each year (Interagency Coordination Group, 2019). Natural products are promising new drug candidates in treating antibiotic-resistant infections. Natural products have evolved in natural selection process adapting to various abiotic and biotic stresses where abundant of undiscovered biologically active metabolites for drug discovery. Natural products have always been an important part of drug discovery and intense research has been conducted in this area since the discovery of penicillin in the forties.

\section{Antibacterial}

Turker and Koyluoglu (2012) reported antibacterial activity of ethanol extract of G. Plicatus against Gram-positive Staphylococcus epidermidis and Staphylococcus pyrogenes and Gram-negative Proteus vulgaris and Klebsiella pneumoniae obtained from disc-diffusion method (Turker and Koyluoglu, 2012). Growth inhibitions (7.25 \pm 0.25 to $12.50 \pm 0.50 \mathrm{~mm}$ ) were compared with positive controls such as chloramphenicol, tetracycline, ampicillin, carbenicillin and erythromycin. In another study, the ethanol and chloroform extracts of G. transcaucasicus showed antibacterial activity against Bacillus subtilis and Staphylococcus aureus at MIC values of $9.275 \mathrm{mg} / \mathrm{ml}$ and $1.17 \mathrm{mg} / \mathrm{ml}$, respectively (Sharifzadeh et al., 2010). The methanol extracts of the bulb, flower and shoot of G. transcaucasicus were evaluated for their antibacterial activity against Bacillus subtilis, Bacillus cereus, Staphylococcus aureus, Escherichia coli and Pseudomonas aeruginosa (Karimi et al., 2018). Overall, the antibacterial activity of shoot extract appeared to be most potent followed by flower and bulb extracts. The main and predominant volatile compounds such as acetic acid (13.6\%), 2,3-Butanediol (43.13\%) and 2-Furancarboxaldehyde (68.77\%) were major in shoot, flower and bulb extracts of G. transcaucasicus, respectively. $G$. nivalis extract has demonstrated moderate anti-staphylococcal activity, with the minimal inhibitory concentration (MIC) value of $19.53 \mu \mathrm{g} / \mathrm{ml}$ (Benedec et al., 2018). Interestingly, G. nivalis extract exhibited comparable antibacterial activity with standard drug, gentamicin. Phytochemical analysis of G. nivalis extract revealed that chlorogenic acid $(2976.19 \pm 12.80 \mu \mathrm{g} / \mathrm{g})$ was the main constituent, followed by $p$-coumaric acid $(73.02 \pm 0.07 \mu \mathrm{g} / \mathrm{g})$, ferulic acid $(26.80 \pm 0.19 \mu \mathrm{g} / \mathrm{g})$, isoquercitrin $(25.08 \pm 0.31 \mu \mathrm{g} / \mathrm{g})$ and quercitrin $(11.13 \pm 0.06 \mu \mathrm{g} / \mathrm{g})$.

\section{Antifungal}

The antifungal activity of ethanol extract of the bulb of $G$. transcaucasicus against yeast Candida albicans stood at MIC values of $19.53 \mu \mathrm{g} / \mathrm{ml}$ to $2,500 \mu \mathrm{g} / \mathrm{ml}$ (Sharifzadeh et al., 2010). A study by Ločárek and colleagues showed that alkaloid extract of the bulb of G. elwesii inhibited the growth of Candida spp. and Lodderomyces elongisporus (Ločárek et al., 2015). Galanthamine was the major compound in the alkaloid extract, followed by tazettine and minute amount of haemantamine as analyzed by GCMS. Benedec et al. (2018) reported antifungal activity of $G$. nivalis against C. albicans and filamentous fungi, Aspergillus brasiliensis (Benedec et al., 2018). Phytochemical analysis showed that chlorogenic acid was the dominant phenolic acid within G. nivalis extract.

\section{Antiprotozoal}

Amaryllidaceae alkaloids have previously been tested to possess antiparasitic activities (Campbell et al., 2000; Toriizuka et al., 2008) 
Antiprotozoal activity of the compounds isolated from alkaloid extract was tested against a panel of parasitic protozoa consisting of Trypanosoma brucei rhodesiense, Trypanosoma cruzi, Leishmania donovani, and Plasmodium falciparum, which are responsible for human African trypanosomiasis (sleeping sickness), American trypanosomiasis, Kalaazar (visceral leishmaniasis) and malaria were evaluated in vitro by Plasmodial FAS-II enzyme inhibition assay (Kaya et al., 2011). Arolycoricidine (+)-haemanthamine, dihydrolycorine, and protopine were active against $T . b$. rhodesiense, while (+)-haemanthamine was active against $T$. cruzi with the $\mathrm{IC}_{50}$ less than $10 \mu \mathrm{g} / \mathrm{ml}$. Arolycoricidine (+)-haemanthamine, stylopine and protopine were reported potentially against $P$. falciparum, where stylopine and protopine exhibited sub-microgram inhibition with the $\mathrm{IC}_{50}$ values of 0.23 and $0.50 \mu \mathrm{g} / \mathrm{ml}$ In addition, stylopine and protopine demonstrated good cytotoxicity (L6 and KB cells) selectivity index grant these compounds as promising lead for further development. The study showed that most of the active compounds are of lycorine typealkaloids, in which $\mathrm{O}$-methylnorbelladine (-)-dihydrolycorine and (+)-8-O-demethylmaritidine are being reported here for the first time from the genus Galanthus. Amaryllidaceae-derived haemanthamine displayed remarkable cytotoxicity against primary mammalian cell line (L6) and the human carcinoma cell line (KB) (Kaya et al., 2011).

Lycorine, an Amaryllidaceae alkaloid from snowdrop possesses strong antimalarial activity (Khalifa et al., 2018). It was potently inhibited the growth of $P$. falciparum, the causative agent of malaria, with a low cytotoxic profile against human hepatocarcinoma cells (HepG2) (Gonring-Salarini et al., 2019).

In general, antimalarial agents manifest their action by targeting enzymes associated with the plasmodial FAS-II biosynthetic pathways (Nair and Staden, 2019). It inhibits DNA topoisomerase-I activity which is required for cell growth in parasites and causes cell cycle arrest in vivo (Cortese et al., 1983). The results suggested that the antimalarial activities of lycorine derivatives might be due to the free hydroxyl groups at C- 1 and C- 2 or esterified as acetates or isobutyrates. The presence of a double bond between C-2 and C-3 is important for the activity (Cedrón et al., 2010; He et al., 2015). Overall, these results suggested that Galanthus spp. is potentialantiprotozoal agent for further development.

\section{Antiviral}

Among the microbes, virus infection has emerged as a leading cause of morbidity and mortality worldwide (Luo and Gao, 2020). Recent outbreak has underscored their prevention as a critical issue in safeguarding public health with very limited number of antivirals drugs, vaccines and antiviral therapies available (Babar et al., 2013).

Lectin from snowdrops is being investigated for its anti-viral potential. The Galanthus nivalis agglutinin (GNA) was identified and purified from the bulb of snowdrop (Van Damme et al., 1987). GNA is known to possess virucidal properties against human immunodeficiency virus (HIV) at the $\mathrm{EC}_{50}=0.12 \pm 0.07 \mu \mathrm{g} / \mathrm{ml}$ to $4.7 \pm 3 \mu \mathrm{g} / \mathrm{ml}$ (Balzarini et al., 2004). The molecular mechanisms of GNA exerting antiviral activities via carbohydrate-binding activities, thereby blocking the entry of the virus into its target cells and transmission of the virus by deleting the glycan shield in its envelope protein, thus neutralizing antibody.

G. elwesii's ethanol extract was tested for its anti-herpes simplex virus (HSV) and anti-sindbis virus (SINV) activity. G. elwesii has higher activity in the virucidal $(8 \mu \mathrm{g} / \mathrm{ml})$ assay than the plaque-forming assay $(24 \mu \mathrm{g} / \mathrm{ml})$ (Hudson et al., 2000). G. elwesii extract was potent against SINV, it showed anti-SINV activity at the dose of $16 \mu \mathrm{g} / \mathrm{ml}$.

Most of the mannose-binding lectins exert anti-coronavirus potential except the lectins from garlic (Keyaerts et al., 2007). They interfered with viral attachment in early stage of replication cycle and suppressed the growth by interacting at the end of the infectious virus cycle. The virucidal effect of GNA against SARS$\mathrm{CoV}$ was recorded at $\mathrm{EC}_{50}$ of $6.2 \pm 0.6 \mu \mathrm{g} / \mathrm{ml}$ (Keyaerts et al., 2007). Other GNA-related lectins may exert anti-influenza activities by competitively blocking the combination of influenza A virus envelope glycoprotein haemagglutinin (HA) with its corresponding sialic acid-linked receptor in the host cell, such as H1N1 (Yang et al., 2013). A study evaluated the antiviral potential of plant lectins from a collection of medicinal plants on feline infectious peritonitis virus (FIPV) infected cells. The results indicated that plants derived mannose-binding lections had strongest anti-coronavirus activitity and Galanthus nivalis was one of the coronavirus-inhibiting plants (Adams, 2020).

To sum up, lectin GNA might be a potential target for further development for its anti-CoV potential. Although no $\mathrm{CoV}$ treatments have been approved, pharmacotherapies for MERS$\mathrm{CoV}$ and SARS-CoV may lay the foundation for treatment of the novel human Coronavirus Disease 2019 (COVID-19).

\section{Antioxidant Activity}

Natural antioxidants play a role in preventing cellular free radicals or reactive oxygen species (ROS) formation as well as facilitating repair process from the damage caused by ROS induced oxidative stress which involves in various chronic diseases, such as atherosclerosis, myocardial infections, cancer and neurodegenerative diseases (Bulduk and Karafakığlu, 2019). Antioxidants can act as chain breakers, radical scavengers, singlet oxygen quenchers, hydroperoxides decomposers, and prooxidative metal ions chelators (Pisoschi et al., 2016).

The antioxidant potential of the aerial and bulb of G. reginaeolgae was determined by free radical scavenging DPPH, lipid peroxidation and $\beta$-carotene bleaching tests (Conforti et al., 2010). The result showed that methanol extracts of aerial and bulb of $G$. reginae-olgae had moderate DPPH scavenging potential. Further fractionation of the extracts indicate that the strongest DPPH scavenging of aerial part was ethyl acetate fraction, while alkaloid fraction of bulb showed highest scavenging potential. The results showed that the DPPH scavenging activity of ethyl acetate and alkaloid fractions of aerial and bulb attributed to their distinct chemical diversity The shoot of G. transcaucasicus exhibited higher antioxidant activities compare to bulb and flower that concurred with the high phenolic and flavonoid compounds in shoot. In a comparative study, the ethanol extract of $G$. woronowii exhibited highest DPPH and 2,2'-azino-bis(3ethylbenzothiazoline-6-sulphonic acid (ABTS) scavenging 
activity $\left(\mathrm{IC}_{50}=28.14 \mu \mathrm{g} / \mathrm{ml}\right.$ and $13.09 \mu \mathrm{g} / \mathrm{ml}$, respectively) (Genç et al., 2019). While dichloromethane extract displayed greater reducing potential in cupric ion reducing power assay that ethanol extract. Antioxidant activity of hexane, dichloromethane and ethyl acetate extracts of G. krasnovii were investigated via DPPH and ABTS radical scavenging and cupric ion reducing power assay (Erenler et al., 2019). Dichloromethane extract demonstrated the highest ABTS activity $\left(\mathrm{IC}_{50}=14.33 \mu \mathrm{g} / \mathrm{ml}\right)$ and reducing power (1.15 $\mu \mathrm{mol} \mathrm{TE} / \mathrm{mg})$. DPPH and ABTS method were also been used to investigate the methanol extracts of the leaf and bulb of three Galanthus spp. (Bulduk and Karafakığlu, 2019). The G. woronowii leaf extract recorded the highest DPPH scavenging activity (77\%), whereas all extracts from G. nivalis, G. elwesii and G. woronowii showed comparable ABTS scavenging activity $(17 \pm$ $0.78-23 \pm 0.64 \mu \mathrm{mol} \mathrm{TE} / 100 \mathrm{~g})$. HPLC analysis showed that content of galantamine was higher in the aerial parts (leaves) when compared to the underground parts (bulbs) which may contributed to the higher scavenging activity of the leaf extract.

Apparently, Galanthus spp. appears to be potent source of antioxidants which are enriched with various phytochemicals phenolic acids, flavonoids, and alkaloids (Karimi et al., 2018). It is envisaged that secondary metabolites from Galanthus spp. may reduce the risk and slow down the progression of chronic diseases including cancers, cardiovascular diseases and neurodegenerative diseases.

\section{Anticancer Activity}

Cancer is a chronic disease, which is account for millions of deaths each year (Tan et al., 2016; Tay et al., 2019). Chemotherapy, radiotherapy and recently, immunotherapy are essential means for the treatment of cancers. Severe toxicity and cell resistance to drugs are the major drawback in conventional cancer therapies. In order to circumvent these issues, new cellular targets and anticancer agents are needed, especially those of natural origin. From 1981 to 2002, natural products were the basis of $74 \%$ of all new chemical entities for cancer (Demain and Vaishnav, 2011).

Eight different Galanthus species were tested for their anticancer activity on Human colorectal carcinoma cells (HCT-116), Human promyelocytic leukemia cells (Hela) and Human cervical cancer cells (HL-60) (Jokhadze et al., 2007). All methanol extracts from the galanthus species showed cytotoxic activities, in which the bulbs had higher activity than the aerial parts. Majority of the species were more active against HCT-116 cells, except G. platyphyllus bulbs were more active against HeLa cells than other cell lines, indicating an interesting specificity that should be investigated in future studies. The bulbs of G. woronowii, G. krasnowii, G. shaoricus and G. alpinus were the most cytotoxic $\left(\mathrm{IC}_{50}<10 \mu \mathrm{g} / \mathrm{ml}\right.$ ) on HCT-116 cells. Lycorine had cytotoxicity against HCT-116, HL-60 and Hela cells with $\mathrm{IC}_{50}$ of $3.1,8.2$, and $9.3 \mu \mathrm{M}$. Meanwhile, galanthamine and tazettine were weakly cytotoxic against HCT-116, HL-60 and Hela cells, with $\mathrm{IC}_{50}>100 \mu \mathrm{M}$. It is suggesting that the present of lycorine in the Galanthus spp contributed to the cytotoxic effects on the tested cancer cells. The search for novel anticancer agents from natural sources has been successful worldwide. For over 50 years, natural products have served us well in combating cancer and is still a priority goal for cancer therapy, due to the chemotherapeutic drugs resistance.

\section{CONCLUSION AND FUTURE PERSPECTIVES}

Natural products remain to be a wealthy source for the identification of novel therapeutic agents for the treatment of human diseases. Plants contain a significant numbers of phytochemical components, most of which are known to be biologically active and responsible for various pharmacological activities. It was demonstrated that plant secondary metabolites are preferred natural antioxidants than synthetic ones due to safety concerns. Given the natural abundance of bioactive compounds in this plant, Galanthus spp. can be recognized as an interesting source of natural products with a wide range of biological activities. This review highlights the importance of bioactive substances of various extracts of Galanthus spp. on anti-cholinesterase inhibitory activity and other diseases, supporting the therapeutic possibilities for the use of snowdrops. The most promising compound is galanthamine which exhibited greater activity than tazettine, crinine and lycorine. However, current research on the underlying mechanism of actions and the exact chemical constituent involved are scarce. Apart from the above mentioned activities, other ethnopharmacological uses of snowdrops need to be substantiated with strong scientific studies for its extensive usage in various therapies. Thus, this review may serve as a guide for future researchers in pharmacology to conduct further studies on these plants by providing different perspective. The discussion is expected to inspire further isolation, identification, mechanism of actions and synthetic studies of the existing and novel active compounds from the Galanthus spp. to gain a better understanding of the basis of the activity at the cellular and molecular level in future.

\section{AUTHOR CONTRIBUTIONS}

The writing was performed by CK, LL, KK, and BG. While WS, WY, PG, LM, AM, KK, and BG provided vital guidance, editing and insight to the work. The project was conceptualized by BG and PG.

\section{FUNDING}

This work was financially supported by Monash Global Asia in the 21st Centrury (GA21) research grants (GA-HW-19-L01 and GAHW-19-S02), Fundamental Research Grant Scheme (FRGS/1/2019/ WAB09/MUSM/02/1 and FRGS/1/2019/SKK08/TAYLOR/02/02), Taylor's University Emerging Grant (TRGS/ERFS/2/2018/SBS/016) and External Industry Grant from Biotek Abadi Sdn Bhd (vote no. GBA-8188A).

\section{ACKNOWLEDGMENTS}

We acknowledge Aaron P. Davis, Senior Research Leader of Plant Resources at Royal Botanic Kew Gardens for his excellent photographs in Figures 2A-D. 


\section{REFERENCES}

Adams, C. (2020). Can red algae and mannose-binding lectins fight coronavirus (COVID-19). J. Plant Med.

Ago, Y., Koda, K., Takuma, K., and Matsuda, T. (2011). Pharmacological aspects of the acetylcholinesterase inhibitor galantamine. J. Pharmacol. Sci. 116, 6-17. doi:10.1254/jphs.11r01cr

Aschan, G., and Pfanz, H. (2006). Why snowdrop (Galanthus nivalis L.) tepals have green marks?. Flora-Morphol. Distrib. Funct. Ecol. Plants 201, 623-632. doi:10. 1016/j.flora.2006.02.003

Ay, E., Gül, M., Açıköz, M., Yarilgaç, T., and Kara, Ş. (2018). Assessment of antioxidant activity of giant snowdrop (Galanthus elwesii Hook) extracts with their total phenol and flavonoid contents. Indian J. Pharm. Educ. Res. 52 (4s), s128-s132. doi:10.5530/ijper.52.4s.88

Ayaz, M., Ullah, F., Sadiq, A., Kim, M. O., and Ali, T. (2019). Editorial: natural products-based drugs: potential therapeutics against Alzheimer's disease and other neurological disorders. Front. Pharmacol. 10, 1417. doi:10.3389/fphar. 2019.01417

Babar, M. M., Zaidi, N. S., Ashraf, M., and Kazi, A. G. (2013). Antiviral drug therapy- exploiting medicinal plants. J. Antivir. Antiretrovir. 5, 028-036. doi:10. 4172/jaa. 1000060

Balzarini, J., Hatse, S., Vermeire, K., Princen, K., Aquaro, S., Perno, C. F, et al. (2004). Mannose-specific plant lectins from the Amaryllidaceae family qualify as efficient microbicides for prevention of human immunodeficiency virus infection. Antimicrob. Agents Chemother. 48, 3858-3870. doi:10.1128/AAC.48. 10.3858-3870.2004

Baytop, T. (1999). Therapy with plants in Turkey. (Past and Present). 2nd Edn. Istanbul, TR: Nobel Medicine Publications.

Benedec, D., Oniga, I., Hanganu, D., Gheldiu, A. M., Puşcaş, C., SilaghiDumitrescu, R., et al. (2018). Sources for developing new medicinal products: biochemical investigations on alcoholic extracts obtained from aerial parts of some Romanian Amaryllidaceae species. BMC Compl. Alternative Med. 18, 226. doi:10.1186/s12906-018-2292-8

Bishop, M., Davis, A. P., and Grimshaw, J. (2001). Snowdrops: a monograph of cultivated galanthus. Netley: Griffin Press.

Bozkurt, B., Coban, G., Kaya, G. I., Onur, M. A., and Unver-Somer, N. (2017). Alkaloid profiling, anticholinesterase activity and molecular modeling study of Galanthus elwesii. South Afr. J. Bot. 113, 119-127. doi:10.1016/j.sajb.2017.08.004

Bozkurt, B., Kaya, G. I., Onur, M. A., and Unver-Somer, N. (2020). Chemoprofiling of some Turkish Galanthus L. (Amaryllidaceae) species and their anticholinesterase activity. South Afr. J. Bot. [Epub ahead of print]. doi:10.1016/ j.sajb.2020.09.012

Bozkurt, B., Kaya, G., Önür, M., Bastida, J., and Somer, N. (2013a). Phytochemical investigation of Galanthus woronowii. Biochem. Systemat. Ecol. 51, 276-279. doi:10.1016/j.bse.2013.09.015

Bozkurt, B., Somer, N., Kaya, G., Önür, M., Bastida, J., Berkov, S., et al. (2013b). GC-MS investigation and acetylcholinesterase inhibitory activity of Galanthus rizehensis. Z. Naturforsch. C Biosci. 68, 118-124. doi:10.5560/ZNC.2013. $68 \mathrm{c} 0118$

Bozkurt-Sarikaya, B., Kaya, G. I., Onur, M. A., Bastida, J., Berkov, S., Unver-Somer, N., et al. (2014). GC/MS analysis of Amaryllidaceae alkaloids in Galanthus gracilis. Chem. Nat. Compd. 50, 573-575. doi:10.1007/s10600-014-1022-9

Bulduk, I., and Karafakıoğlu, Y. S. (2019). Evaluation of galantamine, phenolics, flavonoids and antioxidant content of Galanthus species in Turkey. Int. J. Biochem. Res. Rev. 25, 1-12. doi:10.9734/ijbcrr/2019/v25i130068

Campbell, W. E., Nair, J. J., Gammon, D. W., Codina, C., Bastida, J., Viladomat, F., et al. (2000). Bioactive alkaloids from Brunsvigia radulosa. Phytochemistry 53, 587-591. doi:10.1016/s0031-9422(99)00575-0

Cedrón, J. C., Gutiérrez, D., Flores, N., Ravelo, Á. G., and Estévez-Braun, A. (2010). Synthesis and antiplasmodial activity of lycorine derivatives. Bioorg. Med. Chem. 18, 4694-4701. doi:10.1016/j.bmc.2010.05.023

Conforti, F., Loizzo, M. R., Marrelli, M., Menichini, F., Statti, G. A., Uzunov, D., et al. (2010). Quantitative determination of Amaryllidaceae alkaloids from Galanthus reginae-olgae subsp. vernalis and in vitro activities relevant for neurodegenerative diseases. Pharm. Biol. 48, 2-9. doi:10.3109/ 13880200903029308
Cortese, I., Renna, G., Siro-Brigiani, G., Poli, G., and Cagiano, R. (1983). [Pharmacology of lycorine. 1) Effect on biliary secretion in the rat]. Boll. Soc. Ital. Biol. Sper. 59, 1261-1264.

Coyle, J., and Kershaw, P. (2001). Galantamine, a cholinesterase inhibitor that allosterically modulates nicotinic receptors: effects on the course of Alzheimer's disease. Biol. Psychiatr. 49, 289-299. doi:10.1016/s0006-3223(00)01101-x

Demain, A. L., and Vaishnav, P. (2011). Natural products for cancer chemotherapy. Microb. Biotechnol. 4, 687-699. doi:10.1111/j.1751-7915.2010. 00221.x

Elgorashi, E. E., Zschocke, S., Van Staden, J., and Eloff, J. N. (2003). The antiinflammatory and antibacterial activities of Amaryllidaceae alkaloids. South Afr. J. Bot. 69, 448-449. doi:10.1016/S0254-6299(15)30329-X

Erenler, R., Gená, N. S., Elmasta, M., and Emina Ao Lu, Z. R. (2019). Evaluation of antioxidant capacity with total phenolic content of Galanthus krasnovii (Amaryllidaceae). Turkish J. Biodivers. 2 (1), 13-17. doi:10.38059/ biodiversity. 526833

Genç, N., Yıldız, I., Karan, T., Eminagaoglu, O., and Erenler, R. (2019). Antioxidant activity and total phenolic contents of Galanthus woronowii (Amaryllidaceae). Turkish J. Biodivers. 2, 1-5. doi:10.38059/biodiversity.515111

Gonring-Salarini, K., Conti, R., Andrade, J. P. D., Borges, B. R. J. P., Aguiar, A. C. C., Souza, J. O. D., et al. (2019). In vitro antiplasmodial activities of alkaloids isolated from roots of worsleya procera (Lem.) Traub (Amaryllidaceae). J. Braz. Chem. Soc. 30, 1624-1633. doi:10.21577/0103-5053.20190061

He, M., Qu, C., Gao, O., Hu, X., and Hong, X. (2015). Biological and pharmacological activities of Amaryllidaceae alkaloids. RSC Adv. 5, 16562-16574. doi:10.1039/C4RA14666B

Heinrich, M. (2010). Galanthamine from Galanthus and other Amaryllidaceae-chemistry and biology based on traditional use. Alkaloids Chem. Biol. 68, 157-165. doi:10.1016/s1099-4831(10)06804-5

Hudson, J. B., Lee, M. K., Sener, B., and Erdemoglu, N. (2000). Antiviral activities in extracts of Turkish medicinal plants. Pharm. Biol. 38, 171-175. doi:10.1076/ 1388-0209(200007)3831-SFT171

Interagency Coordination Group (2019). "No time to wait - securing the future from drugresistant infections," in Report to the secretary general of the nations (United Nations). Available at: https://www.who.int/docs/default-source/documents/no-time-to-waitsecuring-the-future-from-drug-resistant-infections-en.pdf?sfvrsn=5b424d7_6

International Union for Conservation of Nature (2018). The IUCN red list of threatened species version.2018. United Kingdom: International Union for Conservation of Nature and Natural Resources.

Jamila, N., Khairuddean, M., Yeong, K. K., Osman, H., and Murugaiyah, V. (2015). Cholinesterase inhibitory triterpenoids from the bark of Garcinia hombroniana. J. Enzym. Inhib. Med. Chem. 30, 133-139. doi:10.3109/14756366.2014.895720

Jokhadze, M., Eristavi, L., Kutchukhidze, J., Chariot, A., Angenot, L., Tits, M., et al. (2007). In vitro cytotoxicity of some medicinal plants from Georgian Amaryllidaceae. Phytother Res. 21, 622-624. doi:10.1002/ptr.2130

Karimi, E., Mehrabanjoubani, P., Homayouni-Tabrizi, M., Abdolzadeh, A., and Soltani, M. (2018). Phytochemical evaluation, antioxidant properties and antibacterial activity of Iranian medicinal herb Galanthus transcaucasicus Fomin. J. Food Meas. Charact. 12, 433-440. doi:10.1007/s11694-017-9656-5

Kaya, G. I., Sarıkaya, B., Onur, M. A., Somer, N. U., Viladomat, F., Codina, C., et al. (2011). Antiprotozoal alkaloids from Galanthus trojanus. Phytochem. Lett. 4, 301-305. doi:10.1016/j.phytol.2011.05.008

Kaya, G. I., Uzun, K., Bozkurt, B., Onur, M. A., Somer, N. U., Glatzel, D. K., et al. (2017). Chemical characterization and biological activity of an endemic Amaryllidaceae species: Galanthus cilicicus. South Afr. J. Bot. 108, 256-260. doi:10.1016/j.sajb.2016.11.008

Keyaerts, E., Vijgen, L., Pannecouque, C., Van Damme, E., Peumans, W., Egberink, H., et al. (2007). Plant lectins are potent inhibitors of coronaviruses by interfering with two targets in the viral replication cycle. Antivir. Res. 75, 179-187. doi:10.1016/j.antiviral.2007.03.003

Khalifa, M., Shihata, E., Refaat, J., and Kamel, M. (2018). An overview on the chemical and biological aspects of lycorine alkaloid. J. Adv. Biomed. Pharm. Sci. 1, 41-49. doi:10.21608/jabps.2018.4088.1016

Khaw, K. Y., Choi, S. B., Tan, S. C., Wahab, H. A., Chan, K. L., and Murugaiyah, V. (2014). Prenylated xanthones from mangosteen as promising cholinesterase inhibitors and their molecular docking studies. Phytomedicine 21, 1303-1309. doi:10.1016/j.phymed.2014.06.017 
Khaw, K. Y., Chong, C. W., and Murugaiyah, V. (2020). LC-QTOF-MS analysis of xanthone content in different parts of Garcinia mangostana and its influence on cholinesterase inhibition. J. Enzym. Inhib. Med. Chem. 35, 1433-1441. doi:10. 1080/14756366.2020.1786819

Kostelník, A., and Pohanka, M. (2018). Inhibition of acetylcholinesterase and butyrylcholinesterase by a plant secondary metabolite boldine. BioMed. Res. Int. 2018, 9634349. doi:10.1155/2018/9634349

Lamoral-Theys, D., Andolfi, A., Van Goietsenoven, G., Cimmino, A., Le Calvé, B., Wauthoz, N., et al. (2009). Lycorine, the main phenanthridine Amaryllidaceae alkaloid, exhibits significant antitumor activity in cancer cells that display resistance to proapoptotic stimuli: an investigation of structure-activity relationship and mechanistic insight. J. Med. Chem. 52, 6244-6256. doi:10. 1021/jm901031h

Lee, M. R. (1999). The snowdrop (Galanthus nivalis): from Odysseus to Alzheimer. Proc. R. Coll. Physicians Edinb. 29 (4), 349-352.

Liew, S. Y., Khaw, K. Y., Murugaiyah, V., Looi, C. Y., Wong, Y. L., Mustafa, M. R., et al. (2015). Natural indole butyrylcholinesterase inhibitors from Nauclea officinalis. Phytomedicine 22, 45-48. doi:10.1016/j.phymed.2014.11.003

Ločárek, M., Nováková, J., Klouček, P., Hošt’álková, A., Kokoška, L., Gábrlová, L., et al. (2015). Antifungal and antibacterial activity of extracts and alkaloids of selected Amaryllidaceae species. Nat. Prod. Commun. 10, 1934578X1501000912. doi:10.1177/1934578X1501000912

Luo, G., and Gao, S. J. (2020). Global health concerns stirred by emerging viral infections. J. Med. Virol. 92, 399-400. doi:10.1002/jmv.25683

Maelicke, A., Coban, T., Storch, A., Schrattenholz, A., Pereira, E. F., and Albuquerque, E. X. (1997). Allosteric modulation of Torpedo nicotinic acetylcholine receptor ion channel activity by noncompetitive agonists. J. Recept. Signal Transduct. Res. 17, 11-28. doi:10.3109/10799899709036592

Mashkovsky, M. D., and Kruglikova-Lvova, R. P. (1951). On the pharmacology of the new alkaloid galantamine. Farmakol. Toxicol. 14, 27-30.

Mesulam, M. M., and Geula, C. (1994). Butyrylcholinesterase reactivity differentiates the amyloid plaques of aging from those of dementia. Ann. Neurol. 36, 722-727. doi:10.1002/ana.410360506

Nair, J. J., and Staden, J. V. (2019). Antiplasmodial lycorane alkaloid principles of the plant family Amaryllidaceae. Planta Med. 85 (8), 637-647. doi:10.1055/a0880-5414

Orhan, I., and Şener, B. (2003). Bioactivity-directed fractionation of alkaloids from some Amaryllidaceae plants and their anticholinesterase activity. Chem. Nat. Compound 39, 383-386. doi:10.1023/B:CONC.0000003421.65467.9c

Orhan, I., and Şener, B. (2005). Sustainable use of various Amaryllidaceae plants against Alzeimer's disease. 678, 59-64. doi:10.17660/ActaHortic.2005.678.7

Paskov, D. (1959). Nivalin: pharmacology and clinical application. Pharmachim, 1.

Pisoschi, A. M., Pop, A., Cómpeanu, C., and Predoi, G. (2016). Antioxidant capacity determination in plants and plant-derived products: a review. Oxid. Med. Cell. Longevity 2016, 9130976. doi:10.1155/2016/9130976

Plaitakis, A., and Duvoisin, R. C. (1983). Homer's moly identified as Galanthus nivalis L.: physiologic antidote to stramonium poisoning. Clin. Neuropharmacol. 6, 1-5. doi:10.1097/00002826-198303000-00001

Proskurnina, N. F., and Areshknina, L. Y. (1953). Alkaloids of Galanthus woronowi. II. Isolation of a new alkaloid. (In English). Chem. Abstr. 47, 6959c.

Resetár, A., Freytag, C., Kalydi, F., Gonda, S., M-Hamvas, M., Ajtay, K., et al. (2017). Production and antioxidant capacity of tissue cultures from four Amaryllidaceae species. Acta Soc. Bot. Pol. 86, doi:10.5586/asbp.3525
Rhee, I. K., Appels, N., Luijendijk, T., Irth, H., and Verpoorte, R. (2003). Determining acetylcholinesterase inhibitory activity in plant extracts using a fluorimetric flow assay. Phytochem. Anal. 14, 145-149. doi:10.1002/pca.695

Rønsted, N., Zubov, D., Bruun-Lund, S., and Davis, A. (2013). Snowdrops falling slowly into place: an improved phylogeny for Galanthus (Amaryllidaceae). Mol. Phylogenet. Evol. 69, 205-217. doi:10.1016/j.ympev.2013.05.019

Sarikaya, B. B., Berkov, S., Bastida, J., Kaya, G. I., Onur, M. A., and Somer, N. U. (2013). GC-MS investigation of Amaryllidaceae alkaloids in galanthus xvalentinei nothosubsp. subplicatus. Nat. Prod. Commun. 8, 327-328. doi:10.1177/1934578X1300800312

Semerdjieva, I., Sidjimova, B., Yankova-Tsvetkova, E., Kostova, M., and Zheljazkov, V. D. (2019). Study on Galanthus species in the Bulgarian flora. Heliyon. 5, e03021. doi:10.1016/j.heliyon.2019

Sharifzadeh, M., Yousefbeyk, F., Amin, G., Sormaghi, M., Azadi, B., Samadi, N., et al. (2010). Investigation on pharmacological and antimicrobial activities of Galanthus transcaucasicus Fomin growing in Iran. Planta Med. 76, P474. doi:10.1055/s-0030-1264772

Sidjimova, B., Berkov, S., Popov, S., and Evstatieva, L. (2003). Galanthamine distribution in Bulgarian Galanthus spp. Pharmazie 58, 935-936.

Tan, H. L., Chan, K. G., Pusparajah, P., Saokaew, S., Duangjai, A., Lee, L. H., et al. (2016). Anti-cancer properties of the naturally occurring aphrodisiacs: icariin and its derivatives. Front. Pharmacol. 7, 191. doi:10.3389/fphar.2016.00191

Tan, W. N., Khairuddean, M., Wong, K. C., Khaw, K. Y., and Vikneswaran, M. (2014). New cholinesterase inhibitors from Garcinia atroviridis. Fitoterapia 97, 261-267. doi:10.1016/j.fitote.2014.06.003

Tay, K. C., Tan, L. T., Chan, C. K., Hong, S. L., Chan, K. G., Yap, W. H., et al. (2019). Formononetin: a review of its anticancer potentials and mechanisms. Front. Pharmacol. 10, 820. doi:10.3389/fphar.2019.00820

Toriizuka, Y., Kinoshita, E., Kogure, N., Kitajima, M., Ishiyama, A., Otoguro, K., et al. (2008). New lycorine-type alkaloid from Lycoris traubii and evaluation of antitrypanosomal and antimalarial activities of lycorine derivatives. Bioorg. Med. Chem. 16, 10182-10189. doi:10.1016/j.bmc.2008.10.061

Turker, A., and Koyluoglu, H. (2012). Biological activities of some endemic plants in Turkey. Rom. Biotechnol. Lett. 17 (1), 6949-6961.

Van Damme, E. J. M., Allen, A. K., and Peumans, W. J. (1987). Isolation and characterization of a lectin with exclusive specificity towards mannose from snowdrop (Galanthus nivalis) bulbs. Fed. Eur. Biochem. Soc. Lett. 215, 140-144. doi:10.1016/0014-5793(87)80129-1

Ventola, C. L. (2015). The antibiotic resistance crisis: part 1: causes and threats. P T. 40, 277-283

World Checklist of Selected Plant Families (2020). World checklist of galanthus. Kew.: Facilitated by the Royal Botanic Gardens.

Yang, J., Li, M., Shen, X., and Liu, S. (2013). Influenza A virus entry inhibitors targeting the hemagglutinin. Viruses 5, 352-373. doi:10.3390/v5010352

Copyright (C) 2021 Kong, Low, Siew, Yap, Khaw, Ming, Mocan, Goh and Goh. This is an open-access article distributed under the terms of the Creative Commons Attribution License (CC BY). The use, distribution or reproduction in other forums is permitted, provided the original author(s) and the copyright owner(s) are credited and that the original publication in this journal is cited, in accordance with accepted academic practice. No use, distribution or reproduction is permitted which does not comply with these terms. 